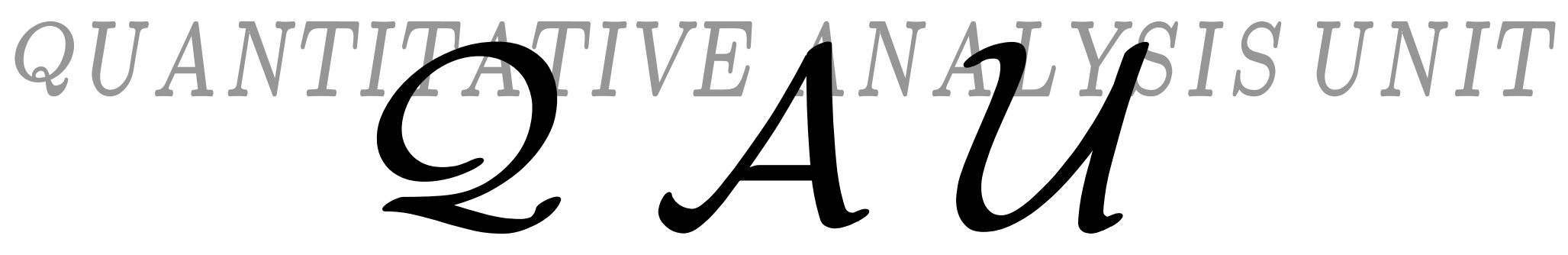

\title{
How Effective Were the Federal Reserve Emergency Liquidity \\ Facilities? Evidence from the Asset-Backed Commercial \\ Paper Money Market Mutual Fund Liquidity Facility
}

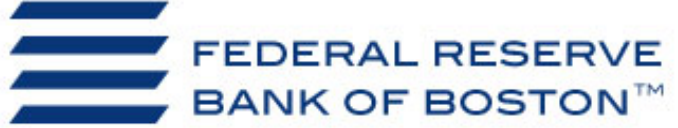

Working Paper No. QAU10-3
Burcu Duygan-Bump

Federal Reserve Bank of Boston

Patrick M. Parkinson

Federal Reserve Board of Governors

Eric S. Rosengren

Federal Reserve Bank of Boston

Gustavo A. Suarez

Federal Reserve Board of Governors

Paul S. Willen

Federal Reserve Bank of Boston

This paper can be downloaded without charge from: The Quantitative Analysis Unit of the Federal Reserve Bank of Boston http://www.bos.frb.org/bankinfo/qau/index.htm

The Social Science Research Network Electronic Paper Collection: http://ssrn.com/abstract=1596677 


\title{
How Effective Were the Federal Reserve Emergency Liquidity Facilities?
}

\section{Evidence from the Asset-Backed Commercial Paper Money Market Mutual Fund \\ Liquidity Facility}

\author{
Burcu Duygan-Bump, Patrick M. Parkinson, Eric S. Rosengren, \\ Gustavo A. Suarez, and Paul S. Willen
}

April 29, 2010

\begin{abstract}
Following the failure of Lehman Brothers in September 2008, short-term credit markets were severely disrupted. In response, the Federal Reserve implemented new and unconventional facilities to help restore liquidity. Many existing analyses of these interventions are confounded by identification problems because they rely on aggregate data. Two unique micro datasets allow us to exploit both time series and cross-sectional variation to evaluate one of the most unusual of these facilities-the Asset-Backed Commercial Paper Money Market Mutual Fund Liquidity Facility (AMLF). The AMLF extended collateralized loans to depository institutions that purchased asset-backed commercial paper (ABCP) from money market funds, helping these funds meet the heavy redemptions that followed Lehman's bankruptcy. The program, which lent \$150 billion in its first 10 days of operation, was wound down with no credit losses to the Federal Reserve. Our findings indicate that the facility was effective as measured against its dual objectives: it helped stabilize asset outflows from money market mutual funds, and it improved liquidity in the ABCP market. Using a differences-in-differences approach we show that after the facility was implemented, money market fund outflows decreased more for those funds that held more eligible collateral. Similarly, we show that yields on AMLF-eligible ABCP decreased significantly relative to those on otherwise comparable AMLF-ineligible commercial paper.
\end{abstract}

J.E.L Classification: E58, G01, G20

Keywords: Federal Reserve, Financial Crisis, Discount Window, Money Market Mutual Funds, Commercial Paper, Asset-Backed Commercial Paper

Duygan-Bump, Rosengren, and Willen are from the Federal Reserve Bank of Boston; and Parkinson and Suarez are from the Federal Reserve Board of Governors.

We thank seminar and conference participants at the Federal Reserve Banks of Atlanta and Boston, the Federal Reserve Board, and especially Steffanie Brady, Bill Nelson, and Bart Simon for their extremely helpful insights and suggestions. Neil Goodson, Jonathan Larson, Jonathan Morse, and Landon Stroebel provided excellent research assistance. The views represented here are those of the authors and not necessarily those of the Federal Reserve Bank of Boston or the Board of Governors of the Federal Reserve System. Please address correspondence to: Burcu.Duygan-Bump@bos.frb.org 


\section{Introduction}

Short-term credit markets experienced unprecedented stresses after the failure of Lehman Brothers in September 2008. In interbank markets, Libor spreads over overnight index swap rates reached over 350 basis points, as many of the largest financial institutions became unwilling to lend to each other. Similarly, in the commercial paper market, outstanding volumes dropped, maturities shortened, and interest rates climbed to record highs relative to overnight index swap rates. The severe strains in shortterm credit markets played a pivotal role in the financial crisis by compounding other funding pressures at financial institutions, with the potential of disrupting credit flows to firms and households. To help restore liquidity to short-term credit markets, the Federal Reserve used its authority to lend to nonbanks in "unusual and exigent circumstances" under Section 13(3) of the Federal Reserve Act, and implemented new and unconventional emergency lending facilities. As a result of these emergency facilities, the purchase of Treasury and agency securities, and other interventions in credit markets, the balance sheet of the Federal Reserve doubled in the fall of 2008.

Given their novelty and size, it is important to understand whether these facilities were effective in stabilizing financial markets. Along these lines, several recent papers evaluate the impact of these policy interventions using aggregate data (e.g., Christensen, Lopez, and Rudebusch (2009), Stroebel and Taylor (2009), Taylor and Williams (2009), and Wu (2009)). However, studies based on aggregate data are subject to important identification problems. As discussed by Hamilton (2009), it is an econometric challenge to isolate the effects of numerous interventions that were introduced simultaneously using aggregate time series data alone. In addition, it is also a challenge to resolve the inherent endogeneity of the Federal Reserve’s response to market conditions.

Fortunately, we have two unique micro datasets that help us evaluate one of these facilities, the AssetBacked Commercial Paper Money Market Mutual Fund Liquidity Facility (henceforth AMLF). The AMLF was created with a dual objective: increasing the liquidity of the asset-backed commercial paper (ABCP) market, and providing a means for money market mutual funds (MMMFs) to liquefy assets to meet the wave of redemptions that followed the failure of Lehman Brothers, thus preventing many money funds from "breaking the buck." ${ }^{1}$ The AMLF is especially interesting, as it was one of the most unusual facilities when viewed against traditional uses of the discount window. The facility was unconventional in two ways. First, in a substantial departure from "traditional"-recourse and over-collateralized-

\footnotetext{
${ }^{1}$ Throughout the paper, we use money market mutual funds (MMMFs), money market funds, and money funds interchangeably, but they all refer to MMMFs.
} 
discount window loans, the Federal Reserve accepted a modest amount of credit risk under the AMLF by issuing non-recourse loans to banks that purchased $\mathrm{ABCP}$ directly from money funds. The ABCP purchased by the bank was pledged as collateral for the loan, but the Federal Reserve did not impose a haircut on the collateral. Second, the facility was created to foster liquidity in secondary markets for ABCP, an asset not typically held by depository institutions. The facility was quickly adopted, and its lending grew very rapidly, reaching about $\$ 150$ billion in its first 10 days of operation.

The first data set we exploit in our analysis of the AMLF is the complete micro-data set of all loans extended under the facility, which identifies the bank receiving the non-recourse loan, the money fund from which the ABCP was purchased, and the characteristics of the ABCP that collateralized the nonrecourse loan from the AMLF. These data, combined with information on money market portfolios, allow us to evaluate which funds made use of the facility, whether the funds utilizing the facility were those that experienced significant redemptions, and whether money funds resumed ABCP purchases once redemptions subsided or whether they continued investing exclusively in safe havens, like Treasury securities. Second, combining the AMLF loans data with historical data for all commercial paper transactions in the U.S. market from the Depository Trust and Clearing Corporation, we are also able to compare how AMLF-eligible commercial paper behaved relative to non-AMLF eligible types of paper.

The micro nature of these data is essential in our econometric identification of the impact and effectiveness of the AMLF. This feature essentially enables us to exploit not just time-series but crosssectional variation to evaluate the AMLF, separately from other roughly contemporaneous government initiatives, such as the temporary insurance offered by the Treasury Department to existing balances on MMMFs. Our identification strategy builds on the fact that the AMLF targeted a single asset, ABCP; while the Treasury Department’s temporary insurance to existing money fund balances, which was announced on the same day the Federal Reserve announced the AMLF, effectively covered all money fund assets. Accordingly, to isolate the impact of the AMLF, we exploit cross-sectional variation across money market mutual funds and within the commercial paper market to better understand the effects more directly attributable to the AMLF. Thus, for example, comparing the yields on the ABCP of a given issuer to those on unsecured paper of issuers with comparable credit quality helps us understand the effects exclusive to the AMLF.

Using these data, we evaluate the AMLF along three dimensions. First, we analyze how the facility was used by studying which funds used the AMLF and describing the characteristics of the ABCP pledged as collateral. Second, we evaluate the impact of the AMLF on short-term markets by looking at 
redemptions faced by MMMFs, portfolio allocations of money funds across different asset classes, and commercial paper spreads. Third, we analyze the perceived impact of the AMLF using an event study on stock returns around the announcement of the facility.

Our results show that the AMLF was quickly accepted as a means of meeting redemptions by providing an important source of liquidity to money funds. It also helped stabilize asset outflows from these funds. Our analysis of the drivers of the facility's use also confirms that the facility provided a much needed liquidity back-stop. Especially during the first two months of operation, when the majority of the AMLF loans were originated, funds that experienced substantial redemptions were the most active users of the facility. Once redemption pressures subsided and market conditions improved, the use of the facility wound down, consistent with the design of an emergency facility. However, during the spring of 2009, the use of the facility became sporadic and was driven by changes in perceived credit risk of the sponsors of ABCP issuers. For example, in our regressions analyzing the characteristics of the pledged ABCP, the coefficient estimates on the CDS spreads of the ABCP sponsors-used as a proxy for credit risk-are insignificant in the first two months of the AMLF but become significant afterwards.

We also show that the AMLF helped to restore liquidity to the ABCP market and drive down ABCP spreads. In particular, we show that, after the AMLF was implemented, yields on ABCP that could be pledged to the AMLF decreased significantly relative to those on similarly rated financial unsecured commercial paper, which could not be pledged to the AMLF. Comparing the overnight yield on an ABCP conduit sponsored by a financial institution with the same financial institution's unsecured commercial paper yields, we find that the AMLF reduced ABCP yields by about 80 basis points, on average.

The rest of the paper is structured as follows. Section 2 reviews the events that followed Lehman Brothers' default and provides institutional background. Section 3 describes the operational details of the AMLF. Section 4 describes our datasets. Section 5 analyzes the use of the facility, and section 6 evaluates its impact on short-term funding markets. Finally, section 7 presents the results of the event study on stock returns around the announcement of the AMLF, and section 8 concludes with policy implications. 


\section{Money market mutual funds and commercial paper during the $\mathbf{2 0 0 8}$ crisis}

Commercial paper is a short-term credit instrument traditionally used by financial and nonfinancial corporations. Since the early 1990s, banks and other financial institutions have structured ABCP programs or conduits to finance the purchase of pools of assets by issuing and rolling over commercial paper that is collateralized by the assets (Covitz, Liang, and Suarez (2009)). To obtain high short-term credit ratings, the bank or financial institution that sponsors or structures the ABCP program typically commits to provide liquidity or credit support that covers all the liabilities of the conduit. Conduits that specialize in buying receivables from clients of the sponsoring bank are known as multi-sellers; those conduits that exclusively hold assets originated by the sponsor are known as single-sellers, and those that buy highly rated securities are referred to as securities arbitrage. Structured investment vehicles (or SIVs) issued ABCP and longer-term liabilities, but not all liabilities were covered by liquidity or credit support contracts. The main investors in the commercial paper issued by corporations and ABCP conduits are money market funds (Kacperczyk and Schnabl (2010)).

Money market mutual funds are promoted as investments with stable values that provide cash on demand. Funds that register with the SEC and adhere to the restrictions of rule 2a-7 in terms of the maturity, quality, and diversification of their assets are allowed to market themselves widely to the public. $^{2}$ Other "cash-like” investment funds that do not register are under a less restrictive regulatory regime and are accordingly also less restrictive in their choice of assets. These funds are marketed only to institutional and high-net-worth investors. Taxable 2a-7 funds that invest exclusively in Treasury and agency securities are known as "government-only funds," while those that invest mostly in short-term instruments other than Treasury and agency securities, such as commercial paper, are referred to as "prime funds."

Figure 1 shows total assets under management for taxable 2a-7 funds during September and October 2008. As shown by the dotted line, prime money market funds marketed to institutional investors experienced massive outflows that depleted assets under management starting on September 15, the day Lehman Brothers filed for bankruptcy. The outflows intensified after one of the oldest prime funds, the Reserve Primary Fund, "broke the buck” on September 16, due to its exposure to commercial paper issued by Lehman. As a consequence of these outflows, total assets managed by institutional prime funds fell $\$ 400$ billion in just a few days. In contrast, assets under management for retail funds, the solid line,

\footnotetext{
${ }^{2}$ The SEC issued rule 2a-7 (17 CFR 270.2a-7) pursuant to the Investment Company Act of 1940.
} 
remained stable, and assets under management for government-only funds, the dashed line, increased substantially.

On September 19, the Treasury Department announced it would offer insurance to existing balances on registered 2a-7 money funds using the Exchange Stabilization Fund. In addition, the Federal Reserve announced its ABCP Money Market Mutual Fund Liquidity Facility (AMLF) to extend non-recourse loans at the primary credit rate to depository institutions and bank holding companies that borrow to finance their purchases of highly rated ABCP from 2a-7 money funds. After the Treasury and Federal Reserve announcements on the morning of September 19, the outflows from prime funds slowed notably. ${ }^{3}$

The tidal wave of redemptions from money funds in the wake of Lehman's bankruptcy was essentially a modern "bank-run." Because sponsors are allowed to round the value of fund shares to the nearest cent, they report a value of one dollar even when the actual net asset value falls as low as 99.5 cents. As a result, if shareholders suspect that the net asset value is a bit below a dollar, and heading lower, they have an incentive to exit the fund at the inflated value of a dollar. If funds do not have enough cash on hand to meet the flood of redemptions, they may have to sell some of their assets. If assets are sold at a discount because of limited secondary market liquidity, the redemptions cause further reductions in net asset values, and the expectation of redemptions becomes yet another reason for investors to run from the funds. In other words, money market funds are subject to runs, similar to commercial banks but without the benefit of deposit insurance.

Even though money funds invest in relatively short-term assets, the average maturity of money fund portfolios may require funds to sell some assets to meet current or expected redemptions. Figure 2 plots the distribution of the weighted average maturity of assets across prime funds and shows that the average maturity of assets is between 35 and 55 days for most funds. While funds hold a small fraction of their portfolios in very liquid assets to meet ordinary redemption requests, this maturity profile implies that the ability to meet redemptions that exceed 'cash' holdings critically depends on the functioning of secondary markets.

To understand what assets prime money funds can sell to meet extraordinary redemption requests, Figure 3 shows the distribution of their assets, as of September 16, 2008. Taken together, unsecured commercial paper and asset-backed commercial paper (or ABCP) accounted for about 45 percent of total

\footnotetext{
${ }^{3}$ Note that the same day, Treasury Secretary Henry Paulson unveiled the plan to buy $\$ 700$ billion in toxic assets through the Troubled Asset Relief Program (TARP).
} 
assets. However, secondary market trades of commercial paper are mostly bid-backs by dealers, and so, even in typical times, are fairly thin. ${ }^{4}$ The primary buyers of commercial paper are money funds, which hold it to maturity. Accordingly, when money funds began to experience large redemptions after Lehman's bankruptcy, dealers were reluctant to buy back commercial paper because of pressures on their own capital and liquidity. Secondary markets for the remaining asset classes other than government securities were also impaired. As a result, money funds pulled back considerably from purchasing new issues in a variety of short-term funding markets.

As shown in Figure 4, spreads of overnight commercial paper rates over the target federal funds rate soared in the week ending September 19. Spreads for ABCP, the dashed line, skyrocketed to between 300 and 400 basis points, dwarfing their levels in August 2007. Spreads also rose notably for AA-rated paper issued by financial and nonfinancial corporations, the solid and dotted lines, respectively. ${ }^{5}$ As shown in Figure 5, commercial paper outstanding fell. In particular, unsecured paper of financial firms, the solid line, dropped about $\$ 70$ billion in the week Lehman Brothers failed. Similarly, ABCP outstanding, shown by the dashed line, dropped about $\$ 40$ billion.

\section{Design and structure of the AMLF}

As discussed in the previous section, in response to the significant outflows from prime money funds and as credit markets began to seize, the Federal Reserve announced a new facility — the AMLF—on Friday, September 19, 2008. The facility was designed with the dual objectives of increasing liquidity in the ABCP market and providing a means for money funds to liquefy assets to meet the wave of redemptions that followed the failure of Lehman Brothers, thus preventing many money funds from "breaking the buck.” The facility became operational the following Monday, September 22.

The Federal Reserve had three primary reasons to intervene and support the money funds, an industry that had grown to $\$ 3.6$ trillion dollars in total assets by the beginning of September 2008, from about

\footnotetext{
${ }^{4}$ See Covitz and Downing (2007) for a review of institutional details of the market for commercial paper. In a typical bid-back, the dealer, acting as intermediary between issuers and investors, buys previously-issued paper from an investor with liquidity needs because the dealer expects to re-sell it to other investors. Data published by the Federal Reserve (http://www.federalreserve.gov/releases/cp/) indicates that the vast majority of commercial paper issuance in the United States is intermediated by dealers.

${ }^{5}$ AA is typically a long-term credit rating category. However, the Federal Reserve defines AA-rated commercial paper as having at least one short-term credit rating of " 1 " or " $1+$," and no short-term credit rating other lower than " 1 ," and as having at least one "AA" long-term rating. The long-term rating criterion does not apply to ABCP issuers.
} 
$\$ 500$ billion in 1990 . $^{6}$ The first reason was preventing a series of failures of solvent but illiquid institutions, in the spirit of Bagehot’s dictum as summarized by Paul Tucker: "[T]o avert panic, central banks should lend early and freely (i.e. without limit), to solvent firms, against good collateral, and at "high rates.”” In fact, this principle guided many of the other "emergency” lending facilities implemented by the Federal Reserve throughout the crisis, such as the Primary Dealer Credit Facility.

Second, the potential failure of money funds posed a systemic threat, as these funds had become the primary investor in many money market instruments. For example, at the beginning of September 2008, money funds held about $45 \%$ of all commercial paper outstanding in the United States. Accordingly, a failure of the money fund industry was feared to have serious repercussions on other institutions and overall credit market conditions, as many businesses and investment vehicles would have had difficulty rolling over their liabilities and would have potentially been unable to finance their operations. Third, a severe disruption in the ABCP market caused by failing money funds would have faced banks with the prospect of taking onto their already strained balance sheets some of the ABCP that they had committed to support. In sum, the failure of money market funds would have further impacted the credit flow to households and firms—an important driver of economic activity. ${ }^{8}$

Accordingly, between this direct threat to overall economic activity and the concern over exacerbating the panic and liquidity problems, the Federal Reserve created the AMLF to extend central bank credit to money funds. However, there were two challenges in providing the liquidity needed by money funds. First, the Federal Reserve could only extend collateralized loans; it could not buy MMMF assets, such as commercial paper. Second, the money funds did not have regular access to the Discount Window and were reluctant to borrow from the Federal Reserve directly. They feared that investors would recognize that leverage would amplify the effects of any fund losses on remaining shareholders and increase their incentive to run. ${ }^{9}$

\footnotetext{
${ }^{6}$ Source: ICI (http://ici.org/pdf/mm_data_2009.pdf).

${ }^{7}$ As quoted in Madigan (2009): http://www.federalreserve.gov/newsevents/speech/madigan20090821a.htm\#fn2

${ }^{8}$ See Baba, McCauley, and Ramaswamy (2009) for a discussion of the role of MMMFs as the largest supplier of dollar funding to the non-U.S. banks, and the associated stress created in the global interbank and foreign exchange markets following the run on money market funds.

${ }^{9}$ In fact, the Board approved the Direct Money Market Mutual Fund Lending Facility (DMLF) as a means of providing direct support to MMMFs on October 3, 2008. However, after consulting with some market participants about operational details of the program, the Board of Governors of the Federal Reserve determined to rescind its approval on October 10, 2008. See: http://www.federalreserve.gov/newsevents/press/monetary/monetary20090311a1.pdf
} 
The AMLF was designed to address these two challenges. Eligible borrowers, which included all U.S. depository institutions, U.S. bank holding companies, and U.S. branches and agencies of foreign banks, were allowed to borrow from the AMLF in order to fund the purchase of eligible ABCP from a money market mutual fund under certain conditions (Figure 6). Only funds that qualify as money market mutual funds under SEC rule 2a-7 were eligible. ${ }^{10}$ The maturity of the loans extended under AMLF would match the remaining maturity of the purchased ABCP, which would be pledged as collateral for the loan. Borrowers were allowed to pledge only the highest rated ABCP, with a maturity restriction of 120 days for depository institutions and 270 days for non-depository institutions. ${ }^{11}$ This indirect design feature of the AMLF allowed the Federal Reserve to effectively lend to money market funds through banks and other traditional discount window borrowers.

Advances by the Federal Reserve Bank of Boston (FRBB) under the facility were non-recourse to the borrower, and the loans were made at the full value of the collateral, rather than at the value less a haircut. As a result, borrowers faced no credit risk on the collateral they pledged, unless the ABCP was deemed to be non-conforming. One of the main reasons for this unconventional design-and a departure from the Bagehot principle — was the already weakened net asset values (NAVs) of money funds and the associated inability to charge a penalty rate for using the facility. Importantly, the AMLF extended loans to depository institutions at the primary credit rate to allow these depository institutions to purchase ABCP from money funds at amortized cost. In strained market conditions, ABCP yields implied by amortized costs are above the primary credit rate charged by the Federal Reserve. This positive spread in the operation incented depository institutions or banks to work with money funds. The key was the fact that amortized cost is distinct from the market value of ABCP, but it was assumed that those market values reflected primarily liquidity troubles. Consistent with that assumption, when the AMLF expired in February 2010, the facility had not experienced any credit losses and generated substantial profits that the Federal Reserve turned over to the Treasury. The underlying idea behind this design was both to help reduce the spreads on $\mathrm{ABCP}$ in the market, as well as to have a facility that automatically winds down as market conditions improve, both of which were achieved as we show below. ${ }^{12}$

\footnotetext{
${ }^{10}$ Eligibility criteria for money funds were revised in June 2009 to ensure that the absence of a penalty rate does not encourage funds to rely inappropriately on the facility and to use it only for liquidity reasons. It specified that only funds experiencing significant redemptions would be qualified to use the facility. These program changes are discussed in detail later in this section.

${ }^{11}$ The ABCP collateral must be rated at the time of pledge and until risk is transferred not be lower than A-1, F1, or P-1. Moreover, only U.S. dollar denominated issues from a U.S. issuer that was actively issuing eligible ABCP to market investors on September 18, 2008 were eligible.

${ }^{12}$ Another key ingredient of the program design that helped its success was the fact that the Federal Reserve interpreted capital and accounting rules in a way that meant that there was no balance sheet or capital impact from
} 
The facility was quickly accepted as a means of meeting redemptions and provided an important source of liquidity to money funds. Lending under the AMLF grew rapidly, reaching about $\$ 150$ billion in its first 10 days of operation (Figure 7). The activity was concentrated in the first weeks of operation and became sporadic in 2009. The facility was utilized by 105 MMMFs, comprising 42 percent of eligible prime funds, through 11 banks and bank holding companies. Despite the potential risks of nonrecourse loans with no haircut imposed on collateral, the Federal Reserve did not suffer any credit losses on its operation of the AMLF. It also suffered from fairly limited moral hazard problems, especially as it relied on limiting eligibility to only high quality paper, together with money funds' risk management and the SEC restrictions on 2a-7 funds. We provide a more detailed analysis, including an econometric model of how the facility was utilized in section 5 .

In June 2009, the Federal Reserve extended the AMLF through February 1, 2010, but adjusted the eligibility criteria for money market funds. In particular, to ensure that the AMLF was used for its intended purpose of providing a temporary liquidity backstop to MMMFs, the Federal Reserve established a redemption threshold whereby access to the AMLF was limited to money market funds that experienced material outflows, defined as at least 5 percent of net assets in a single day or at least 10 percent of net assets within the prior five business days.

\section{Data}

We combine two unique micro-level datasets with publicly available data to evaluate the AMLF and to disentangle its impact on money funds and the commercial paper market from the effects of other government initiatives. First, we have the complete dataset of loans extended through the AMLF, which identifies the bank receiving the non-recourse loan, the money fund from which the bank purchased the ABCP collateralizing the loan, and the characteristics of the ABCP collateral. Maintaining confidentiality about the borrowers, we use these data to analyze a number of interesting questions: how the facility was used, how it impacted funds utilizing the facility compared with other funds, whether funds utilizing the facility were those that experienced significant redemptions, and whether money funds resumed ABCP purchases once redemptions subsided or if they continued investing exclusively in safe havens, like Treasury securities.

their intermediary role. Otherwise, it would have been very difficult to convince the banks to participate given the pressures on their balance sheets. 
We combine the AMLF data with money fund characteristics taken from iMoneyNet. iMoneyNet is the primary source of data on money market mutual funds, tracking over 1,600 money funds_-including the vast majority of the 2a-7 funds that were eligible to utilize the AMLF. For each fund, iMoneyNet reports weekly portfolio composition by asset class, as well as total assets under management and weighted average maturity information collected at a daily and weekly frequency. Money funds voluntarily report these data to iMoneyNet via the accountant, transfer agent, and/or portfolio manager, and hence are potentially subject to self-reporting errors. For example, even though iMoneyNet routinely cross-checks the data for accuracy, there seems to be a small number of funds that do not report their holdings of $\mathrm{ABCP} .^{13}$

Unless otherwise stated, our sample is limited to prime money market mutual funds. This sample criterion excludes taxable government-only funds (which invest exclusively in Treasury and agency securities) and tax-exempt funds (which invest in tax-exempt securities), restricting our sample to 250 funds, 105 of which utilized the AMLF. ${ }^{14}$ For the most part, we focus on a relatively narrow window around the announcement of the AMLF. However, we also use the full sample period available from the AMLF, especially incorporating data from May through June 2009, when the facility made its last loans after the Federal Reserve tightened the eligibility criteria for the AMLF. These data shed better light on our analysis on how the facility was utilized as well as its long-term impact on short-term markets and possible distortions it may have created.

To analyze the impact of the AMLF on the commercial paper market and to compare how AMLFeligible commercial paper behaved relative to other types of commercial paper, we use data from the Depository Trust Company Corporation (DTCC), the agent that electronically clears and settles all commercial paper transactions in the U.S. market. We collect data for 170 ABCP programs that issued paper in the primary market from September 2008 to September 2009. Using data from Moody's Investors Service, we identify the financial institution that sponsors each ABCP program. ${ }^{15}$ We obtain data on the unsecured commercial paper issued by the sponsoring institutions from DTCC and data on CDS spreads for the sponsors from Markit.

\footnotetext{
${ }^{13}$ Missing observations for ABCP and other asset share variables in iMoney are interpreted to be zero, unless the missing data follows a reported share of 5 percent or greater. In this case, the missing data are interpreted as true reporting error and the previous value is carried forward.

${ }^{14}$ Funds are defined at the Master Class level, which by definition refers to the portfolio level definition. We drop roughly 30 percent of AMLF loans (in both number and dollars), because we are unable to match the AMLF loans to money funds in the iMoneyNet dataset.

${ }^{15}$ ABCP conduits also have liquidity providers and credit enhancement providers that affect the pricing of their paper but for many conduits these are the same as the sponsoring institution.
} 
Finally, for our event study, we use data from CRSP and COMPUSTAT to compute stock returns and asset capitalization for money fund managers and other firms in the S\&P 500 index around the AMLF announcement on September 19, 2008.

\section{How was the facility used?}

At its peak of activity on October 1, 2008, the AMLF held \$152 billion of loans (see Figure 7), which corresponds to roughly 22 percent of ABCP outstanding at the time. On that day, loans at the AMLF matched paper of 81 different conduits. Throughout the life of the facility, the average ratio of paper pledged in the AMLF to total paper outstanding in the market for each program was 21 percent. ${ }^{16}$ Overall, 90 out of the 170 active unique $\mathrm{ABCP}$ issuers and 47 out of the 71 unique active sponsors were represented in the AMLF pledges. ${ }^{17}$ These pledges were relatively concentrated at the sponsor level, where 50 percent of the total lending was against ABCP issued by 15 issuers, and sponsored by 5 institutions (Table 1).

On the user side, 11 intermediary institutions, including banks and broker dealers, borrowed from the AMLF to buy ABCP from 105 prime MMMFs, which represent 42 percent of AMLF-eligible individual prime funds. Table 2 presents summary statistics about the portfolio composition and other characteristics of all eligible prime funds and those that participated in the AMLF. Institutional funds, which suffered the largest redemptions after Lehman's bankruptcy, accounted for 57 percent of all eligible funds and 64 percent of the funds that used the facility. Compared to all eligible prime funds, those funds that used the AMLF held more ABCP on average (about 18 percent versus 12 percent) and less liquid assets ${ }^{18}$ (about 15 percent versus 21 percent), as might be expected. The use of the facility among funds was also fairly concentrated, both at the individual fund level and at the fund complex level: 6 individual funds coming from 3 fund complexes accounted for 25 percent of the loans extended under the AMLF, and 17 individual funds of 6 fund complexes accounted for half of the loans (Table 3).

In terms of loan characteristics in our main sample, Table 4 shows that, the average loan size was \$68 million with an average maturity of 47 days (and a maximum of 168 days). Figure 8 shows the distribution of the remaining maturity of the ABCP pledged as collateral to the facility, in other words the

\footnotetext{
${ }^{16}$ Source: AMLF and DTCC data.

${ }^{17}$ Active as of September 18, 2008, as defined in the eligibility criteria of the facility.

${ }^{18}$ Liquid assets are defined as Treasury securities, repos, and U.S. agency securities.
} 
maturity of the loans. A third of the collateral had remaining maturities of 1-4 weeks and about half of them had remaining maturities of 2-3 months.

\subsection{Money market mutual funds' decision to participate}

To understand how the AMLF was utilized by MMMFs, we first estimate a probit model, where the left-hand side variable captures a fund's decision to whether or not to participate in the AMLF. Formally, using a panel of daily observations, where the dependent variable is the probability that a money fund uses AMLF on a given day, we estimate the following model:

$$
\operatorname{Pr}\left(I_{i t}^{F}=1\right)=F\left(\beta_{0}+\beta_{1} \ln A_{i t}+\beta_{2} \Delta A_{i t}+\beta_{3} S_{i t}^{A B C P}+\beta_{4} S_{i t}^{L}+\beta_{6} L i q_{i t}\right)
$$

where $I_{i t}^{F}$ is an indicator variable that equals one if fund $i$ used AMLF at time $t ; F$ is the cumulative distribution function of a normal distribution; $\ln A_{i t}$ is logarithm of total assets under management (AUM) by fund $i$ at time $t ; \Delta A_{i t}$ is the percentage change in total AUM between $t-1$ and $t ; S_{i t}^{A B C P}$ is the share of ABCP holdings in fund $i$ 's portfolio at time $t$; $S_{i t}^{L}$ is the share of "liquid" assets, defined as repos, Treasuries, and other U.S. agency notes ${ }^{19}$ of fund $i$ at time $t$; and $L i q_{i t}$ is the 7-day liquidity of the fund, defined as the fraction of assets in fund i's portfolio that are scheduled to reach maturity within 7 days from day $t$. We also estimate equation (1) including fund fixed effects.

Table 5 presents the marginal effects of the estimated coefficients from this probit model. We find that the funds with larger redemptions were indeed more likely to have used the AMLF. Similarly, we also find that funds with a larger share of ABCP in their portfolios were more likely to use the facility. In line with our expectations, money funds with higher portfolio shares invested in liquid assets were less likely to tap the AMLF. These findings are not just statistically but also economically significant: a 1\% drop in assets increased the likelihood of a fund's participation by $3.2 \%{ }^{20}$

Next, we run these regressions separately for three sub-samples-September-October 2008, November 2008, and May 2009_instead of using the pooled sample. ${ }^{21}$ The analysis of these sub-periods

\footnotetext{
${ }^{19}$ Other U.S. Agency notes are basically obligations of the Federal National Mortgage Association (FNMA), the Government National Mortgage Association (GNMA), and the Federal Home Loan Mortgage Corporation (FHLMC).

${ }^{20}$ As reported in Table 2, a 1\% drop in assets corresponds to roughly 0.5 standard deviations decrease in assets of money funds on September 9, 2008.

${ }^{21}$ Note that we can only do this analysis for three periods in our data: September/October (pooled as there are only a few days in September with AMLF's initiation being September 22), November, and May. This is because AMLF borrowing was very scarce in other months.
} 
allows us to explore the possibility that funds' behavior or motivation to use the AMLF may have changed over time, responding to market and credit conditions. Although the facility seems to have quickly been accepted as a means of meeting redemptions and have provided an important source of liquidity to money funds, the results for different subsamples, reported in Table 6, suggest that redemptions were no longer a key driver of the AMLF activity by the spring of 2009. This is also in line with the sporadic nature of the activity that we observe once redemptions from money funds subsided.

In addition, we study the determinants of the amount of funds borrowed from the facility, which equals the volume of ABCP pledged as collateral at the facility to obtain the loans. Table 7 reports the results of estimating a Tobit model on the volume of ABCP pledged to the facility by fund $i$ at time $t$, normalized by fund i's AUM, using the same explanatory variables as in equation (1). Similarly, Table 8 reports the results of estimating this Tobit model, but scaling the dependent variable by the total ABCP holdings of the fund. The results in Table 7 and 8 are roughly consistent with the findings of the probit model estimated in equation (1). In particular, funds that experienced larger percentage decreases in assets (i.e., larger redemptions) or that held a smaller share of liquid assets borrowed more from AMLF, both as share of ABCP holdings at the fund or as a share of total fund assets. In statistical terms, the ABCP share in the portfolio of a fund appears to be positively correlated with the volume borrowed from the facility measured in terms of ABCP holdings, but not with the volume borrowed measured in terms of total assets.

\subsection{Collateral pledged to the facility}

We also examine the characteristics of the collateral that funds pledged to the AMLF to obtain loans through depository institutions eligible for the discount window. In particular, we study whether certain types of ABCP programs (e.g., those that carry higher credit risk) were more likely to be pledged to the facility, or whether aggregate market conditions, including liquidity pressures, were the main drivers of the type of collateral pledged to the facility. To answer this question, we use a panel of daily observations of all conduits that issued AMLF-eligible paper in the U.S. market (non-extendible issues rated at least A1/P-1) to estimate a probit model for the probability that ABCP issued by conduit or program $i$ was pledged to the facility on day $t$ :

$$
\operatorname{Pr}\left(I_{i t}^{P}=1\right)=F\left(\beta_{0}+\beta_{1} P_{i}+\beta_{2} C D S_{S(i) t}+\beta_{3} t\right)
$$

where $I_{i t}^{P}$ is an indicator variable that equals 1 if ABCP program $i$ is pledged to the facility on day $t ; F$ is the cumulative distribution function of a standard normal variable; $P_{i}$ is a vector of program type dummy 
variables (multi-seller, single-seller, securities arbitrage, structured investment vehicle, and other); $C D S_{S(i) t}$ is the 5-year premium (in percent) on credit default swaps for the sponsor of ABCP program $i$ (or $s(i)$ ). Sponsors are matched to ABCP programs using reports from Moody's Investors Service for each ABCP issuer. Sponsor CDS spreads are taken from Markit, and we use them to proxy for the credit risk of each individual ABCP issuer. ${ }^{22}$ To capture changes in aggregate market conditions, including liquidity pressures, we include daily time fixed effects and we estimate equation (2) separately for each month in our sample. We obtain similar results if we replace the time dummies with Libor spreads over the overnight index swap.

Table 9 reports the marginal effects of this probit model, where robust standard errors clustered by sponsor are reported in brackets. These results suggest that ABCP program credit risks were not the main driver of use in the first weeks of the facility, during which the liquidity pressures on the funds were very high. In fact, in the early months of the operation of the AMLF, aggregate factors captured by the time fixed effects, appear to explain an important part of the variation of the dependent variable, as implied by the higher pseudo R-square numbers after inclusion of time effects (Panel A vs. Panel B in Table 9).

The results are very different for the latter months of our sample: the coefficient on the CDS spread is statistically insignificant during the first part of our data but becomes significant afterwards. In other words, once the aggregate liquidity pressures subsided and the use of the facility became more sporadic, the use of the facility was driven by changes in perceived credit risk of the ABCP conduits pledged as collateral and especially of their sponsors. ${ }^{23}$ These results are not just statistically but economically significant as well. As shown in Panel A, even after controlling for program type dummies and aggregate conditions (as measured by time fixed effects), a one standard deviation (384 basis-point) increase in the CDS spread of the sponsor implies for example a 5.4\% increase in the likelihood that ABCP associated with that sponsor would be pledged to the AMLF in November 2008. Interpreting the coefficients over time, however, is confounded by the low-level of activity and its sporadic nature especially after October, 2008. Overall, though, one should note that the majority (about 80\%) of the lending activity of the AMLF was concentrated in September and October 2008, and the type of collateral pledged during this period is not explained by credit risk of the sponsor of ABCP.

\footnotetext{
${ }^{22}$ During the height of the crisis, CDS spreads very likely reflected some liquidity risk as well, but they do remain one of the best available indicators of credit risk.

${ }^{23}$ Standard \& Poor's Ratings Service placed its ratings on a significant number of national and regional banks, as well as their various units, on watch for downgrade a few days ahead of when the federal government was due to release results of its stress tests. (Wall Street Journal, May 4, 2009.)
} 
These results suggest that, when faced with significant redemption pressures, funds pledged all the ABCP they held, not only the relatively riskier collateral. Similarly, funds that did not need liquidity may have wanted to hold on to the higher risk paper for yield reasons. Another factor that might have limited the ability of funds to transfer risk to the AMLF is the relatively prudent risk management by MMMFs. In part because of the restrictions imposed by rule 2a-7, MMMFs tend to hold "better quality" ABCP than the average investor in the market. ${ }^{24}$

\section{Evaluating the impact of the AMLF}

In evaluating the impact of the AMLF, we consider two perspectives corresponding to the facility's dual objective-MMMFs and commercial paper markets. First, we analyze the impact of AMLF's announcement on redemptions (net asset outflows) from MMMFs. Second, we analyze the impact of the AMLF on commercial paper spreads. Finally, we examine the impact of the AMLF on fund portfolios and check whether money funds resumed ABCP purchases once redemptions subsided or if they continued investing exclusively in safe havens, like Treasury securities.

\subsection{Money market mutual funds' net asset flows: Did AMLF help ameliorate redemptions?}

We first look at how asset flows responded to the announcement of the AMLF. Using a panel of daily observations encompassing one week before and one week after the announcement of the AMLF (September 12-26, 2008), we estimate the following equation:

$\Delta A_{i t}=\beta_{0}+\beta_{1} A M L F_{\bar{t}}+\beta_{2} S_{i \hat{t}}^{A B C P}+\beta_{3} A M L F_{\bar{t}} * S_{i \hat{t}}^{A B C P}+\beta_{4} S_{i \hat{t}}^{L}+\beta_{5} L i q_{i \hat{t}}+\beta_{6}$ Inst $_{i}+\varepsilon_{i t}$ (3)

where $\Delta A_{i t}$ is the change in total AUM of fund $i$ between $t-1$ and $t ; A M L F_{\bar{t}}$ is an indicator variable that equals 1 after September 19, 2008 (we denote the announcement date of the AMLF by $\bar{t}$ )). $S_{i \hat{t}}^{A B C P}$ is the share of ABCP holdings in fund i's portfolio on September 9, 2008 (one week before Lehman's bankruptcy, which we denote by $\hat{t}))$; $S_{i \hat{t}}^{L}$ is the share of "liquid" assets defined as repos, Treasuries, and other U.S. agency notes of fund $i$ at time $\hat{t}$, Inst $t_{i}$ is a dummy variable for institutional MMMFs; and $L i q_{i \hat{t}}$ is the 7-day liquidity of the fund, defined as the percent of assets in fund $i$ 's portfolio that are scheduled to reach maturity within 7 days from $\hat{t}$. We also estimate equation (3) including fund and time (day) fixed effects.

\footnotetext{
${ }^{24}$ A comparison of the yields of the paper held at the AMLF and the average yield in the market in fact supports this argument as they show the former to be lower. Results from this exercise are available from the authors upon request.
} 
Note that the identification of the impact of the AMLF relies not just on the time-series variation (captured by the dummy that equals 1 after $\mathrm{AMLF}-A M L F_{\bar{t}}$ ) but also on the cross-sectional variation across MMMFs with respect to their ABCP holdings, the interaction term between $A M L F_{\bar{t}}$ and $S_{i \hat{t}}^{A B C P}$. We expect that funds with higher holdings of ABCP to benefit more from the AMLF. By contrast, all money funds would benefit to same extend from other government initiatives that were announced around the same time, in particular the Treasury guarantee covering the existing balances on money funds as of September 19, 2008. More formally, under the hypothesis that the AMLF helped to reduce outflows from money funds beyond other government interventions, the coefficient on the interaction term in equation (3), $\beta_{3}$, should be positive and significant, indicating more inflows (or lower redemptions) after the AMLF is implemented, particularly for funds with larger portfolio shares allocated to ABCP. ${ }^{25}$

Table 10 presents the results of estimating equation (3). Consistent with the hypothesis that the AMLF helped to stabilize net asset flows to MMMFs, we find that, regardless of the specification used, the coefficient on the interaction term is indeed positive and highly significant. Our results also show that institutional funds and funds with higher holdings of ABCP at the time of Lehman's bankruptcy indeed suffered higher level of outflows. However, the liquidity positions of the funds are not statistically significant predictors of asset flows. We suspect that this is primarily because there is generally little variation across prime funds with respect to their holdings of Treasury securities or repos, assets that comprised a relatively small share of their portfolios.

\section{2. $\quad$ Commercial paper spreads}

To analyze the impact of the AMLF on commercial paper spreads, we again rely heavily on the micro nature of our unique data. In particular, we carry out a difference-in-difference estimation and compute how the yield on ABCP changed compared to the yields on the unsecured paper of its own sponsor around the announcement of the AMLF. More formally, we use a panel of daily observations of ABCP conduits that issued AMLF-eligible paper in the U.S. market from September 16 to September 24, 2008 to estimate the following equation:

$$
\begin{gathered}
r_{i, t}^{A B C P}-r_{S(i), t}^{C P} \\
=\beta_{0}+\beta_{1} A M L F_{\bar{t}}+\beta_{2} C D S_{S(i), t}+\beta_{3} A M L F_{i}+\beta_{4} A M L F_{i} * A M L F_{\bar{t}}+\beta_{4} P_{i}+\varepsilon_{i t}
\end{gathered}
$$

\footnotetext{
${ }^{25}$ The left-hand side variable, the percentage change in assets, is the negative of outflows or redemptions from money funds.
} 
where $r_{i, t}^{A B C P}$ is the overnight yield on ABCP conduit $i ; r_{s(i), t}^{C P}$ is the overnight yield on unsecured commercial paper issued by the financial institution that sponsors conduit $i ; A M L F_{\bar{t}}$ is an indicator variable that equals 1 after September 19, 2008, when the AMLF was implemented (the "AMLF Dummy”); $C D S_{S(i), t}$ is the premium on the 5-year credit default swap of the ABCP program sponsor; $A M L F_{i}$ is a dummy that equals 1 for ABCP programs pledged to the AMLF over its first month of operation; and $P_{i}$ is a vector of ABCP program type fixed effects (the categories included are multi-seller, single-seller, securities arbitrage, and structured investment vehicle).

Table 11 reports the results from estimating equation (4), using specifications that include conduit fixed effects, sponsor fixed effects, and time fixed effects. In all specifications, we cluster standard errors by sponsor. Under the hypothesis that the AMLF helped to reduce ABCP yields beyond the impact of other government interventions, the coefficient on the interaction term in equation (4), $\beta_{4}$, should be negative. In other words, a negative coefficient on the interaction term indicates that ABCP programs perceived as potential collateral for the facility experienced larger reductions in yields after the facility was announced.

Similar to the results for outflows from money market funds, we find in Table 11 that the impact of the AMLF was significant. Column (1) reports the results of estimating equation (4) imposing the restriction that all coefficients other than $\beta_{0}$ and $\beta_{1}$ are zero. The coefficient on the AMLF dummy in column (1) suggests that the facility led to a decrease in ABCP yields of 78 basis points for the average conduit, compared with the yields of unsecured commercial paper issued by its sponsor. The findings are similar, even after we control for program or sponsor fixed effects. For example, the estimates reported in column (5) suggest that the AMLF reduced the yields on the ABCP that was pledged to the facility by 69 basis points on average, after controlling for sponsor and ABCP program fixed effects. These magnitudes are especially significant considering that average yields during this period were $4.8 \%$ for ABCP and $2.2 \%$ for unsecured financial paper.

\subsection{Money market mutual funds' portfolios}

When evaluating the impact of the AMLF, we also consider changes in MMMF portfolios and how shares of each asset evolved in response to the facility. In particular, we study whether money funds resumed $\mathrm{ABCP}$ purchases once redemptions subsided or if they continued investing exclusively in safe havens, like Treasury securities. 
Panel A of Figure 9 plots the shares of major asset classes for all prime funds from August 2008 to October 2009, and Panel B plots the corresponding shares for the subset of funds that participated in AMLF. This figure marks both the implementation of the AMLF, announced on September 19, 2008, and the changes to eligibility criteria and the extension of the program until February 1, 2010, which were announced on June 25, 2009. The second announcement provides a natural data point to analyze whether the program had significant longer term effects on money markets. In particular, we can study whether money funds continued relying on the facility many months after redemptions had ebbed.

The portfolio shares plotted in Figure 9 suggest that the AMLF provided an important source of liquidity for MMMFs in the weeks following the failure of Lehman Brothers, allowing funds to sell their $\mathrm{ABCP}$ holdings to meet the redemption requests. Moreover, Figure 9 also indicates that money funds that used AMLF resumed purchases of ABCP after redemptions subsided and also bolstered the liquidity of their portfolios. ${ }^{26}$ However, as market conditions improved and use of the AMLF ebbed, the impact of the facility on portfolios seems to have diminished as well. In fact, the announcement of changes to the facility in June 2009 elicited only a muted response on money fund portfolios. We believe this is an indicator of the success of the facility, which provided important back-stop liquidity but introduced minimal permanent distortions.

Another interesting observation, comparing Panel A and Panel B in Figure 9, is the more pronounced changes in ABCP and liquid asset shares among AMLF participants around the Lehman bankruptcy. This is in line with our findings in section 5 that AMLF participant funds had indeed higher shares of ABCP and suffered more redemptions.

Unfortunately, data on asset shares are available only at a weekly frequency, and thus we are unable to repeat the differences-in-differences-type of analysis along the lines of the previous two sections. However, we believe these figures provide interesting insights on the impact of the facility, both immediately after the AMLF was established and over the longer run.

\section{Market perception of the AMLF: An event study}

In this section, we conduct an event study to test whether stock market investors perceived AMLF as an effective tool for supporting money funds after the bankruptcy of Lehman Brothers. More concretely,

\footnotetext{
${ }^{26}$ A more thorough analysis of the funds' portfolios is needed to better understand the implications of broader factors, including the challenges of a low-rate environment and the overall decrease in the amount of ABCP outstanding in 2008-2010. We leave this question for a future paper, however, due to space considerations.
} 
we analyze the impact of AMLF on the stock return of money fund managers. Money fund managers are the publicly traded firms most likely to be impacted by a Federal Reserve facility aimed at providing emergency liquidity to money funds. We focus on money fund managers, rather than on money fund themselves, because money funds registered under rule 2a-7 report fixed NAVs.

Money fund managers typically provide advice and administer individual money market mutual funds (MMMFs) in exchange for fees that are proportional to total assets managed. Even though money fund managers are not contractually obligated to absorb losses from MMMFs, earnings of money fund managers may be reduced significantly when money funds experience substantial redemptions that may cause money funds to "break the buck.” First, because of reputational concerns, some money fund managers may purchase troubled assets from their funds at par value, effectively absorbing losses. As documented by Baba, McCauley, and Ramaswamy (2009), many money fund managers actually supported money funds in 2007 and 2009. The following letter to the SEC illustrates the type of support provided by money managers:

"Due to current market conditions, the Funds have been met with extraordinary shareholder redemptions related to recent events in the markets. We anticipate that redemption requests may accelerate in upcoming days. In order to meet such redemptions under current market conditions, the Funds would need to liquidate portfolio securities, such as the Securities, at disadvantageous market prices not reflecting their full value were they held to maturity. Accordingly, the Advisers believe, and based on information provided by the Advisers, each Fund's Board of Trustees has determined, that it would not be in the best interests of the Funds and their shareholders to dispose of the Securities in the market in such a manner. However, subject to obtaining the no action assurance requested in this letter, the Purchaser is prepared to purchase certain of the Securities from the Funds for cash at each Security's amortized cost (including accrued and unpaid interest) to the extent necessary to allow the Funds to pay redemption proceeds.” Letter to the SEC from Morgan Stanley, September 18, $2008 .{ }^{27}$

The second reason why fund managers are likely to be affected by substantial money fund redemptions is because management fees are proportional to assets under management and redemptions reduce the income from fees associated with the fund. Finally, the manager may be forced to waive at least part of their fees to prevent redemptions and keep investors in their funds.

In a typical event study, part of the strength of the methodology stems from estimating stock returns on a tight window around the news event. For example, absent other news events on the day AMLF was announced, the event study methodology calls for comparing the stock return of firms that manage money

\footnotetext{
${ }^{27}$ Source: SEC No Action Letters.
} 
funds with the stock return of firms that do not manage money funds. However, the simple event study methodology for AMLF faces the significant challenge of a contemporaneous policy announcement: on the same day the Federal Reserve announced and implemented the AMLF (September 19, 2008), the Treasury Department announced an insurance program on existing balances of money funds. Therefore, a finding of relatively higher stock returns for money fund managers around September 19, 2008 would be attributable to the joint efforts of the Federal Reserve and the Treasury, as well as the news about Troubled Asset Relief Program (TARP).

To isolate the effect of the AMLF from that of the Treasury guarantee program and other announcements that were made on the same day, we exploit the differential effect of the AMLF on money fund managers that are more likely to be impacted by a facility that provides more assistance to funds with ABCP holdings. More specifically, we exploit the fact that AMLF targeted only ABCP and, accordingly, is likely to have a stronger impact on money fund managers with larger exposures to prime funds than on money fund managers with larger exposures to Treasury-only funds or tax-exempt funds, which do not hold ABCP. Furthermore, the AMLF is more likely to have a positive effect on fund managers with larger exposures to funds with substantial ABCP holdings. On the contrary, the Treasury guarantee program was not specifically targeted to prime money market funds or to those with larger portfolio allocations to ABCP. Indeed, all 2a-7 funds were offered access to the guarantee program in exchange for a fee.

Using data from iMoneyNet, we identify publicly traded money fund managers and measure their exposures to money funds. In particular, we measure the overall exposure of a money fund manager to the money fund industry by adding assets under management for all money funds managed by the firm. For each money fund manager, we also observe the share of assets under management in prime funds and the share of prime fund assets that are held as ABCP. Finally, we define the sample of our event study as the set of financial firms that are either part of the S\&P 500 index or are publicly traded money fund managers but excluded from the S\&P 500 index. This sample restriction leaves us with 94 companies. We identify 36 publicly traded money fund managers, 28 of which are also firms in the S\&P 500 index.

Using stock price data from CRSP for S\&P 500 firms and DataStream for all other firms, we compute stock returns for the firms in our sample over a three-day window around September 19, 2008, when AMLF was announced and implemented. More formally, we estimate:

$$
R_{i}=\beta_{0}+\beta_{1} K_{i}+\beta_{2} M_{i}+\varepsilon_{i},
$$


where $R_{i}$ is the stock return of firm $i$ from September 18 to September 22, 2008; $K_{i}$ represents firm size, as measured by the $\log$ of market capitalization, and $M_{i}$ is an indicator variable that captures Money Fund Exposure and equals 1 for firms identified as money fund managers.

Table 12 reports the results of this baseline specification. We find that stocks returns were roughly 5 percentage points larger for money fund managers relative to other firms in our sample with no direct exposure to money funds. As shown by the second column, we also find a positive impact of money fund exposure on stock returns when measuring the exposure as the ratio of money fund assets under management to the money fund manager's market capitalization. The fact that firms with direct money fund exposures outperform the rest of the sample may be jointly attributed to the AMLF and the Treasury guarantee program announced on the same day.

To isolate the effect of the AMLF from other announcements made on September 19, we expand the set of explanatory variables of this regression to include firm characteristics to capture money fund managers who were more likely to use the AMLF. The third column of Table 12 measures money fund exposure using the ratio of money fund assets to market capitalization and includes the fraction of money fund assets held in prime funds managed by the firm. Since only prime funds hold ABCP, they are more likely to benefit from the AMLF. On the contrary, the Treasury guarantee program was offered to both prime fund and to other types of funds that do not buy ABCP for their portfolios. Consistent with that prediction, the regression in the third column shows that firms that managed a relatively larger share of assets in prime funds experienced larger stock returns even when compared to other money fund managers.

Similarly, the fourth column of Table 12 measures money fund exposure using the ratio of money fund assets to market capitalization and includes both the fraction of money fund assets held in prime funds and the fraction of ABCP in prime fund assets. Interestingly, we find that money fund managers that managed funds with larger ABCP shares in their portfolios experienced relatively larger stock returns around the time the AMLF was announced and implemented.

The results of our event study suggest that firms with money fund exposures experienced relatively larger stock returns than firms with no money fund exposures, particularly those with exposures to prime money funds with larger shares of ABCP holdings. The relatively higher stock return of money fund managers with exposures to prime funds and with larger ABCP holdings is more distinctively 
attributable to the AMLF than to other contemporaneous announcements that impacted all money fund managers, like the Treasury guarantee program.

\section{Conclusions}

This paper evaluates one of the emergency lending facilities implemented by the Federal Reserve in response to the 2008-2009 financial crisis—the Asset-Backed Commercial Paper Money Market Mutual Fund Liquidity Facility (AMLF). We find that the AMLF was effective, as measured against its dual objectives: Our results suggest that the AMLF provided an important source of liquidity to MMMFs and the ABCP market, as it helped to stabilize MMMF asset flows and to drive down ABCP yields. We also find that the facility very likely helped money funds to continue investing in ABCP and commercial paper, instead of turning entirely into safe assets, such as Treasury securities, which would have further added to the already severe credit market pressures that followed the failure of Lehman Brothers. Finally, we find that the AMLF had a positive impact on stock returns of money fund managers, particularly those with larger exposures to ABCP.

Although the AMLF and many of the Federal Reserve's emergency liquidity interventions were instrumental in restoring stability in the short term, it is important for the long term to address the financial system's weaknesses as exposed by the crisis. For example, the events of September 2008 highlighted the inherent susceptibility of MMMFs to runs. This susceptibility arises due to a number of features of these funds, including maturity mismatch between their assets and liabilities, a net asset value (NAV) rounded to a \$1 per share, portfolios with credit and interest-rate risk, and discretionary sponsor support instead of formal capital buffers or insurance. Runs on money funds may threaten the broader economy, as firms and industries depend on money markets for funding. Given the temporary nature of the AMLF, there is a need to consider ways to reduce the systemic risk posed by money market funds. In 2010, the SEC changed rule 2a-7 that governs money funds, imposing more stringent requirements on liquidity, credit risk, weighted average maturities, and disclosure. However many questions remain open, such as whether or not to keep a fixed NAV, whether to have insurance or some form of capital buffers, or whether there is a need for a permanent liquidity facility. 


\section{References}

Baba, Naohiko, Robert N McCauley, and Srichander Ramaswamy, 2009, “US dollar money market funds and non-US banks,” BIS Quarterly Review, March, pp 65-81.

Christensen, Jens, Jose Lopez, and Glenn Rudebusch, 2009, "Do central bank liquidity facilities affect interbank lending rates?” Federal Reserve Bank of San Francisco Working Paper, 2009-13.

Covitz, Dan and Chris Downing, 2007, "Liquidity or credit risk? The determinants of very short-term corporate yield spreads,” Journal of Finance, vol 62(5), pp 2303-28.

Covitz, Daniel, Nellie Liang, and Gustavo Suarez, 2009, “The Evolution of a Financial Crisis: Panic in the Asset-Backed Commercial Paper Market,” Finance and Economics Discussion Series 2009-36, Board of Governors of the Federal Reserve System.

Hamilton, James D., 2009, “Evaluating targeted liquidity operations,” Remarks prepared for the Federal Reserve Bank of Boston Annual Conference, October 16.

Kacperczyk, Marcin and Philipp Schnabl, 2010, "When Safe Proved Risky: Commercial Paper during the Financial Crisis of 2007-2009,” Journal of Economic Perspectives, vol 24(1), pp 29-50.

Madigan, Brian F., 2009, "Bagehot's dictum in practice: Formulating and implementing policies to combat the financial crisis,” Remarks prepared for the Federal Reserve Bank of Kansas City's Annual Economic Symposium, Jackson Hole, Wyoming, August 21.

Stroebel, Johannes C. and John B. Taylor, 2009, “Estimated Impact of the Fed’s Mortgage-Backed Securities Purchase Program,” NBER Working Paper No. 15626.

Taylor, John B. and John C. Williams, 2009, “A black swan in the money market,” American Economic Journal: Macroeconomics, vol 1(1), pp 58-83.

Wu, Tao, 2009, “An Empirical Evaluation of the TAF, PDCF, and TSLF,” Working Paper Federal Reserve Bank of Dallas. 
Figure 1: Total assets under management, prime and government-only money market mutual funds, September-October 2008

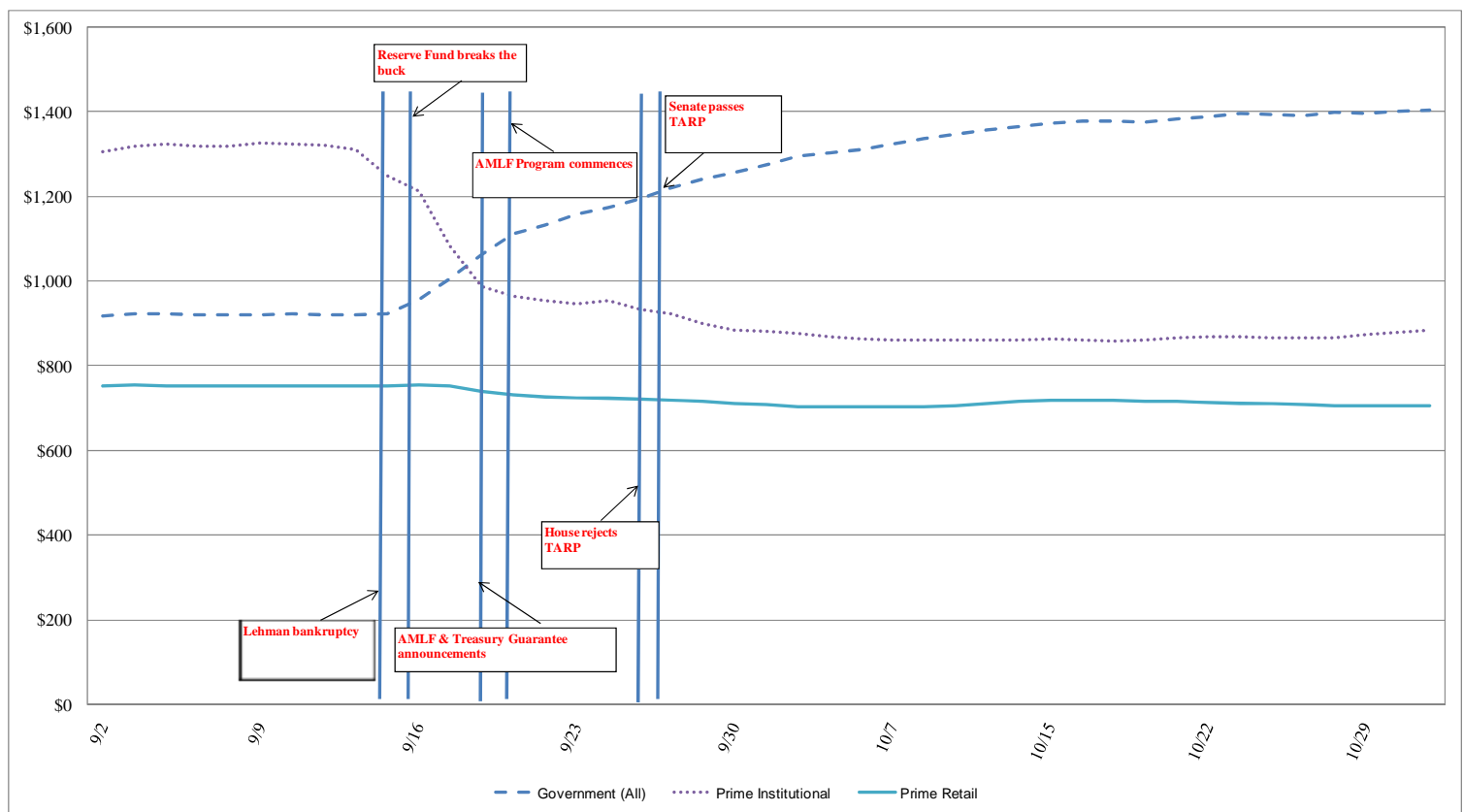

Notes: This figure represents assets under management (in billions of dollars) for all taxable 2a-7 money market funds. The dashed line represents assets of government-only funds, which invest exclusively in Treasury and agency securities. Prime money market funds invest mostly in short-term instruments other than Treasury and agency securities. The dotted line represents assets of prime money market funds marketed to institutional investors. The solid line represents assets of prime money market funds marketed to retail investors.

Source: iMoneyNet. 
Figure 2: Distribution of weighted average maturity of assets across all prime money market mutual funds, September 16, 2008

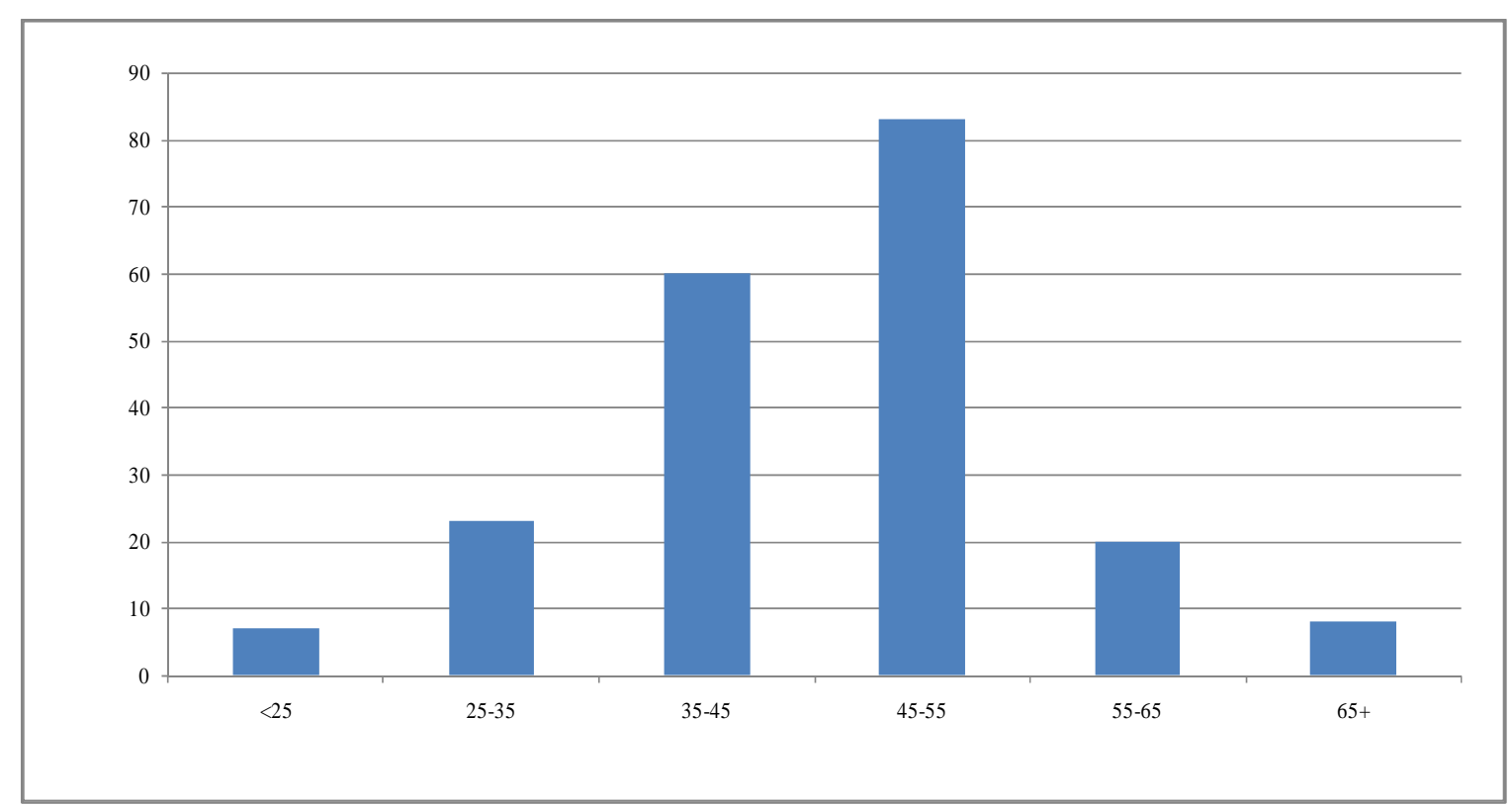

Notes: The horizontal axis represents intervals of weighted average maturity (WAM) in days. The vertical axis represents the number of active prime money market mutual funds as of September 16, 2008. For example, the first bar shows that 7 funds had a weighted average maturity of less than 25 days.

Source: iMoneyNet. 
Figure 3: Asset allocation of prime money market mutual funds, September 16, 2008

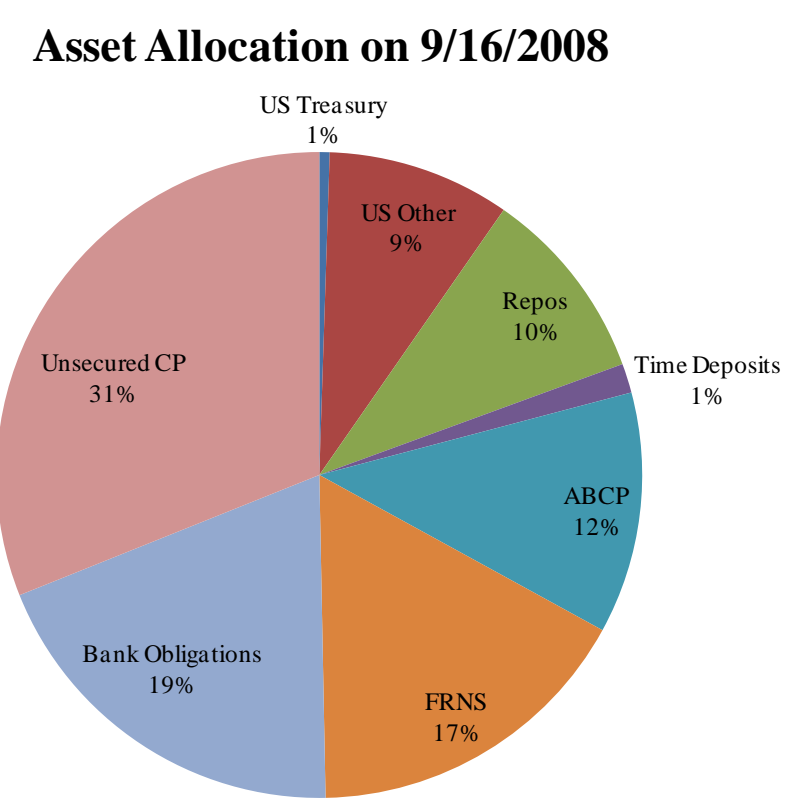

Notes: This figure presents the distribution of assets in prime money market mutual funds as of September 16, 2008. Unsecured $\mathrm{CP}$ represents commercial paper issued by financial and nonfinancial corporations; ABCP represents asset-backed commercial paper; and FRNS represents floating rate notes issued by financial institutions.

Source: iMoneyNet. 
Figure 4: Spreads on overnight commercial paper over the effective fed funds rate

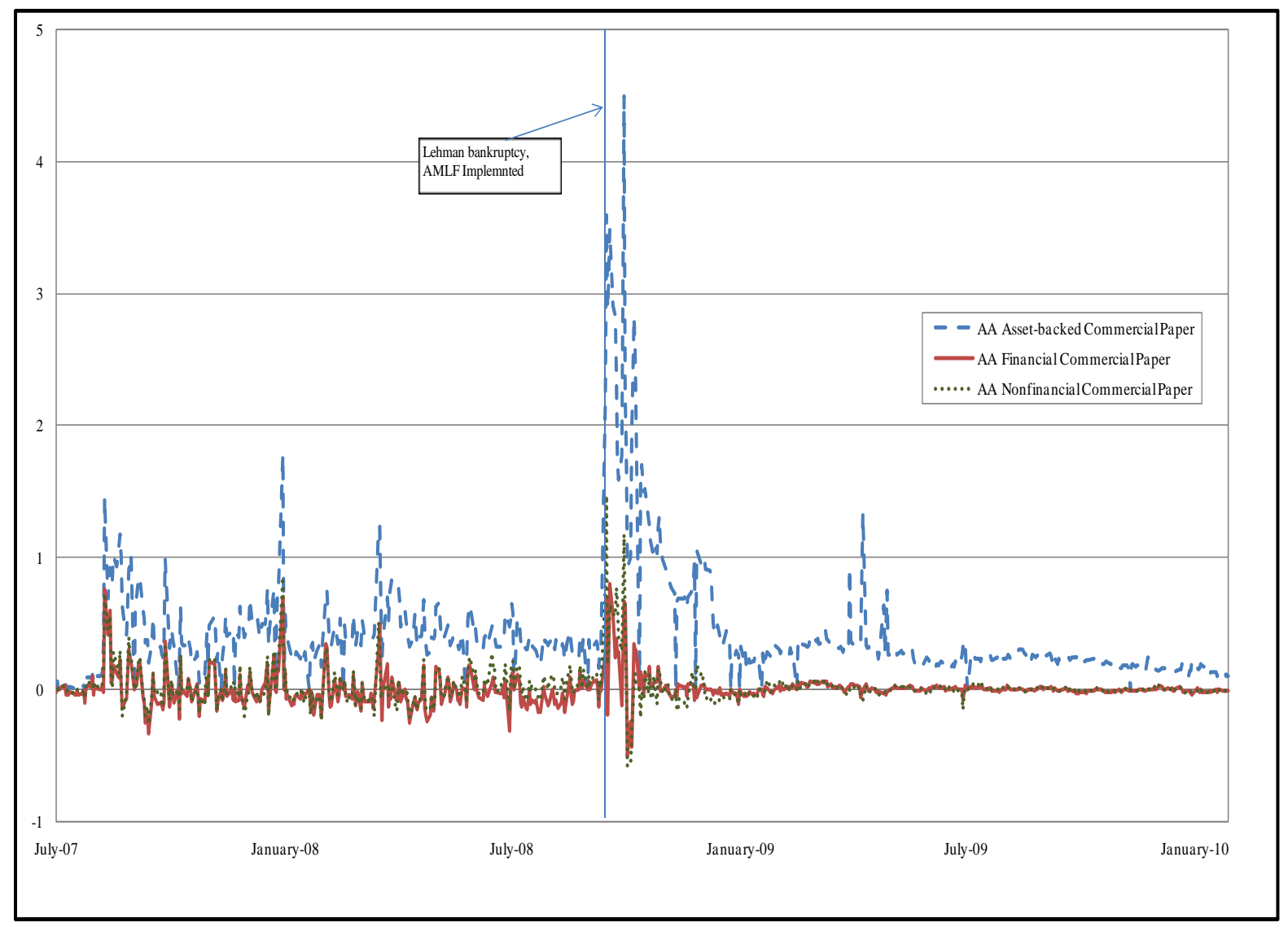

Notes: This figure shows daily overnight commercial paper spreads of the target federal funds rate from July 2007 to January 2010. The dashed line is the spread of AA-rated asset-backed commercial paper; the dotted line is the spread of AA-rated commercial paper issued by nonfinancial corporations; and the solid line is the spread of AA-rated commercial paper issued by financial corporations. Spreads are expressed in percentage points.

Source: CP statistical release, Federal Reserve Board. 
Figure 5: Commercial paper outstanding in the United States, July 2007-January 2010

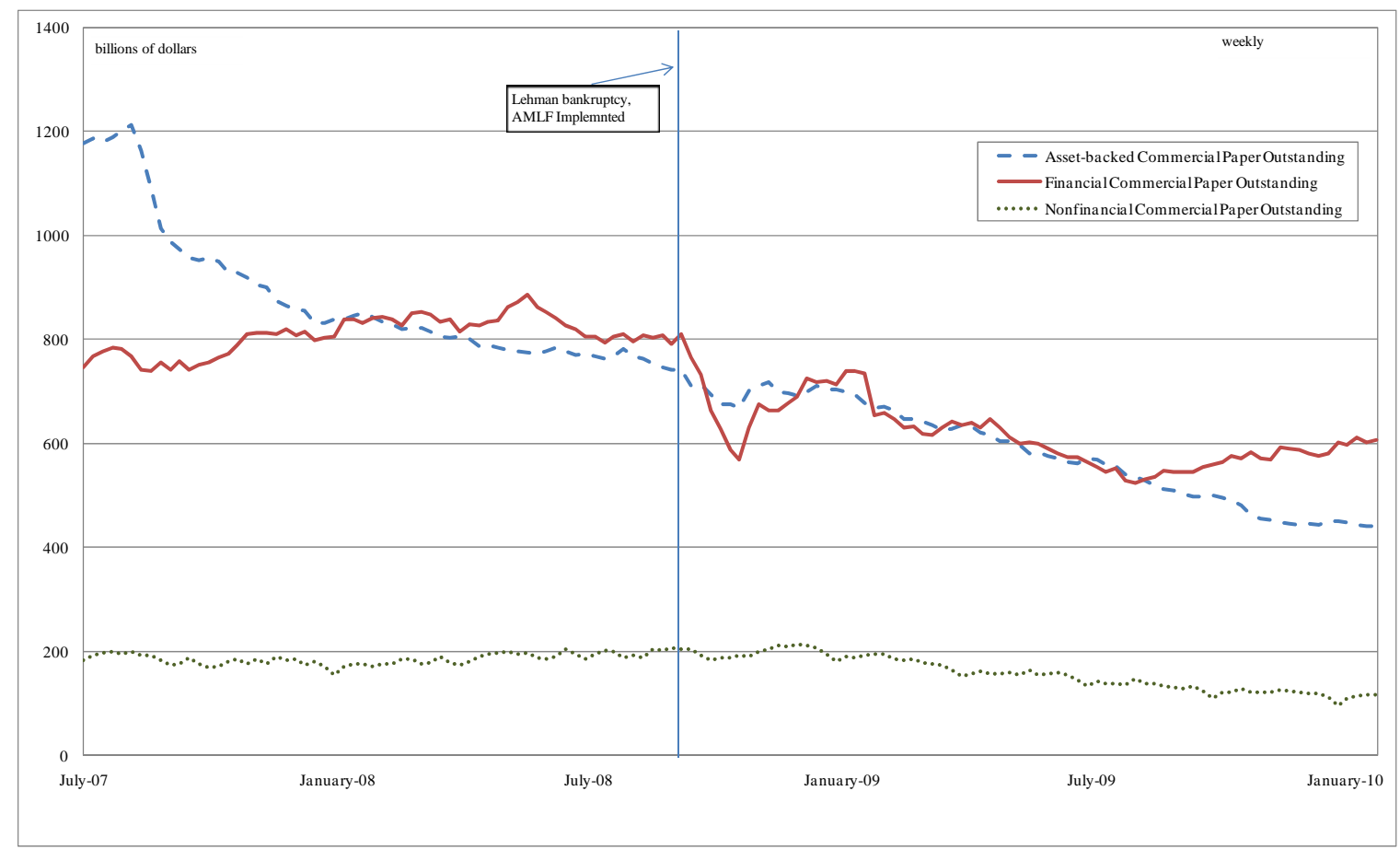

Notes: This figure shows weekly commercial paper outstanding in the United States in billions of dollars from July 2007 to January 2010. The dashed line represents asset-backed commercial paper outstanding, the solid line represents commercial paper outstanding at financial corporations, and the dotted line represents commercial paper outstanding at nonfinancial corporations. Source: CP statistical release, Federal Reserve Board. 
Figure 6: Structure of the Asset-Backed Commercial Paper Money Market Mutual Fund Liquidity Facility (AMLF)

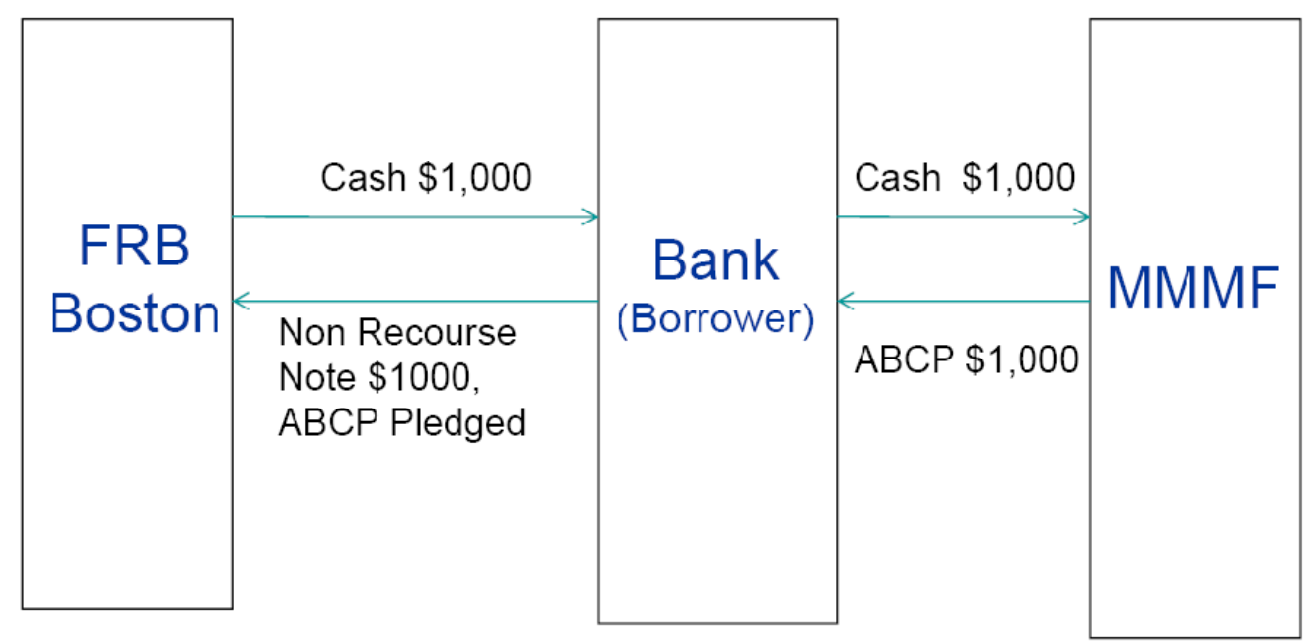

Notes: This figure represents the operation of the Asset-Backed Commercial Paper Money Market Fund Liquidity Facility (AMLF) using a stylized transaction, where a money fund obtains $\$ 1,000$ in funds. The first box represents the Federal Reserve Bank of Boston, the second box represents the eligible borrower (U.S. depository institutions, U.S. bank holding companies, and U.S. branches and agencies of foreign banks), and the last box represents an eligible money market fund (qualifying as a money market mutual fund under SEC rule 2a-7). In the stylized AMLF loan, an eligible borrower purchases asset-backed commercial paper (ABCP) from an eligible money fund at its amortized cost of $\$ 1,000$. The eligible borrower obtains a non-recourse loan for $\$ 1,000$ from the Federal Reserve Bank of Boston with the same maturity as the remaining maturity of the ABCP at the primary credit rate and pledges the $\$ 1,000 \mathrm{ABCP}$ as collateral. The Federal Reserve Bank of Boston does not impose a haircut on the collateral. 
Figure 7: Loans extended through the Asset-Backed Commercial Paper Money Market Liquidity Facility (AMLF), September 2008 to September 2009

Loan balances (weekly average)

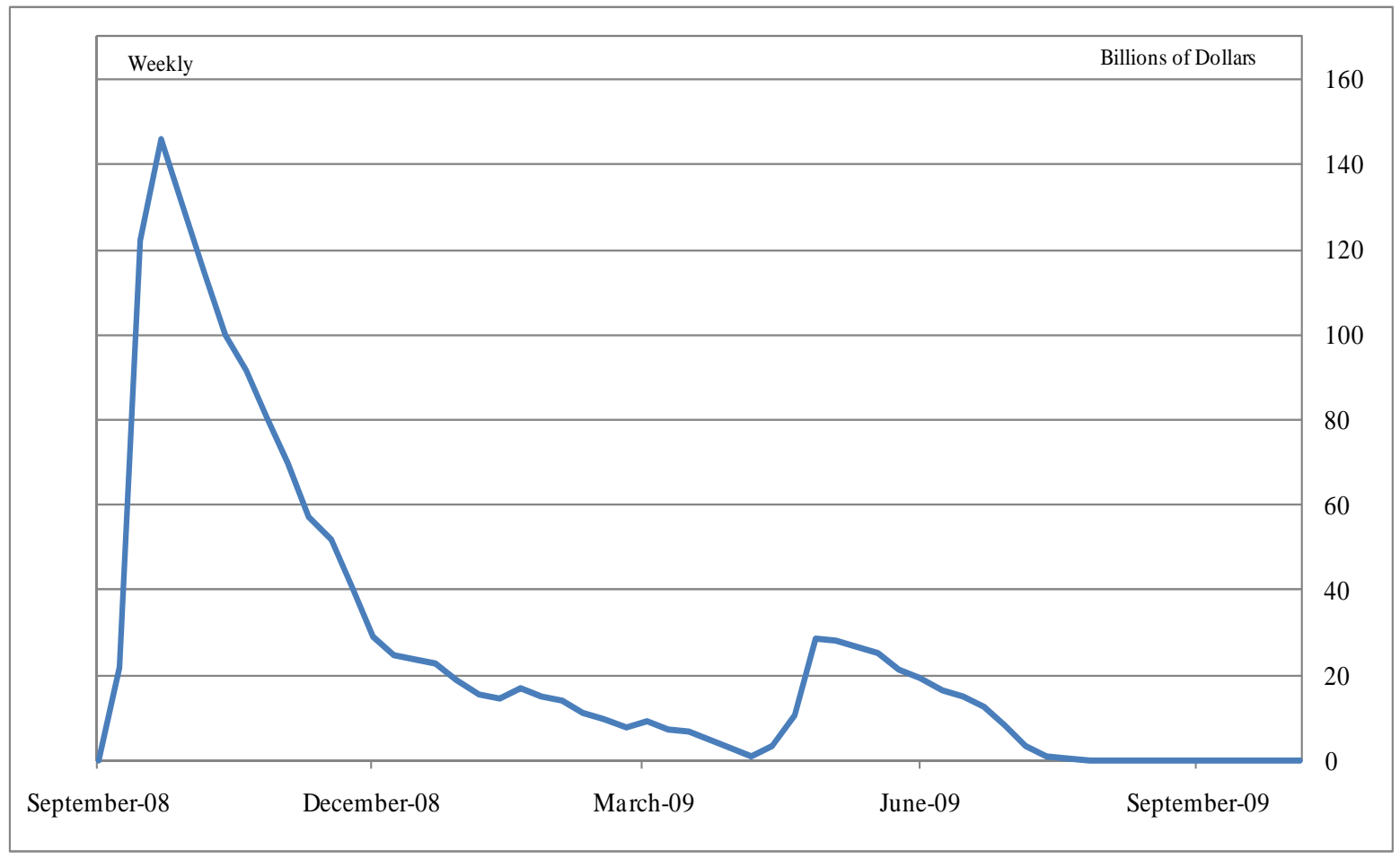

Notes: The figure plots the volume of loans outstanding at the Asset-Backed Commercial Paper Money Market Mutual Fund Liquidity Facility (AMLF) in billions of dollars. Data are measured at a weekly from September 2008 to September 2009. Source: Factors Affecting Reserve Balances (H.4.1), Federal Reserve Board. 
Figure 8: Maturity structure of the asset-backed commercial paper (ABCP) pledged to the $\mathrm{ABCP}$ Money Market Mutual Fund Liquidity Facility (AMLF)

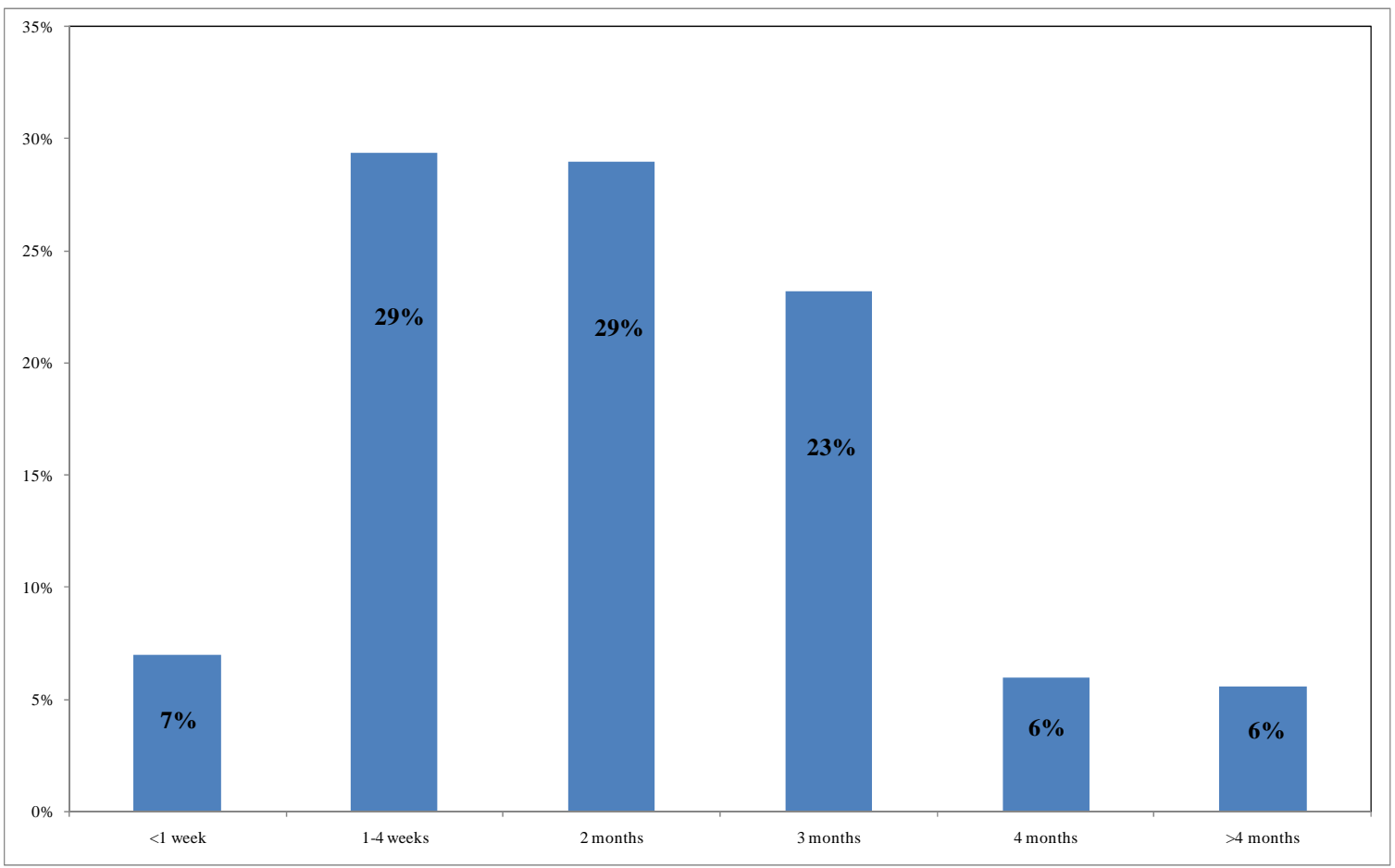

Notes: Maturity of the loans are defined as follows: For eligible borrowers that are not depository institutions, advances may remain outstanding for the remaining term of the ABCP that is financed, which varies from overnight to 270 days. For eligible borrowers that are depository institutions, no advance under the AMLF may exceed a term of 120 days and the maturity of the underlying pledged ABCP may not exceed 120 days. Prepayment in full or part is not allowed except in the event of bankruptcy or receivership of the borrower.

Source: AMLF, Federal Reserve Bank of Boston 
Figure 9: Distribution of assets within money market mutual fund (MMMF) portfolios, August

2008-June 2009

Panel A: All prime MMMFs

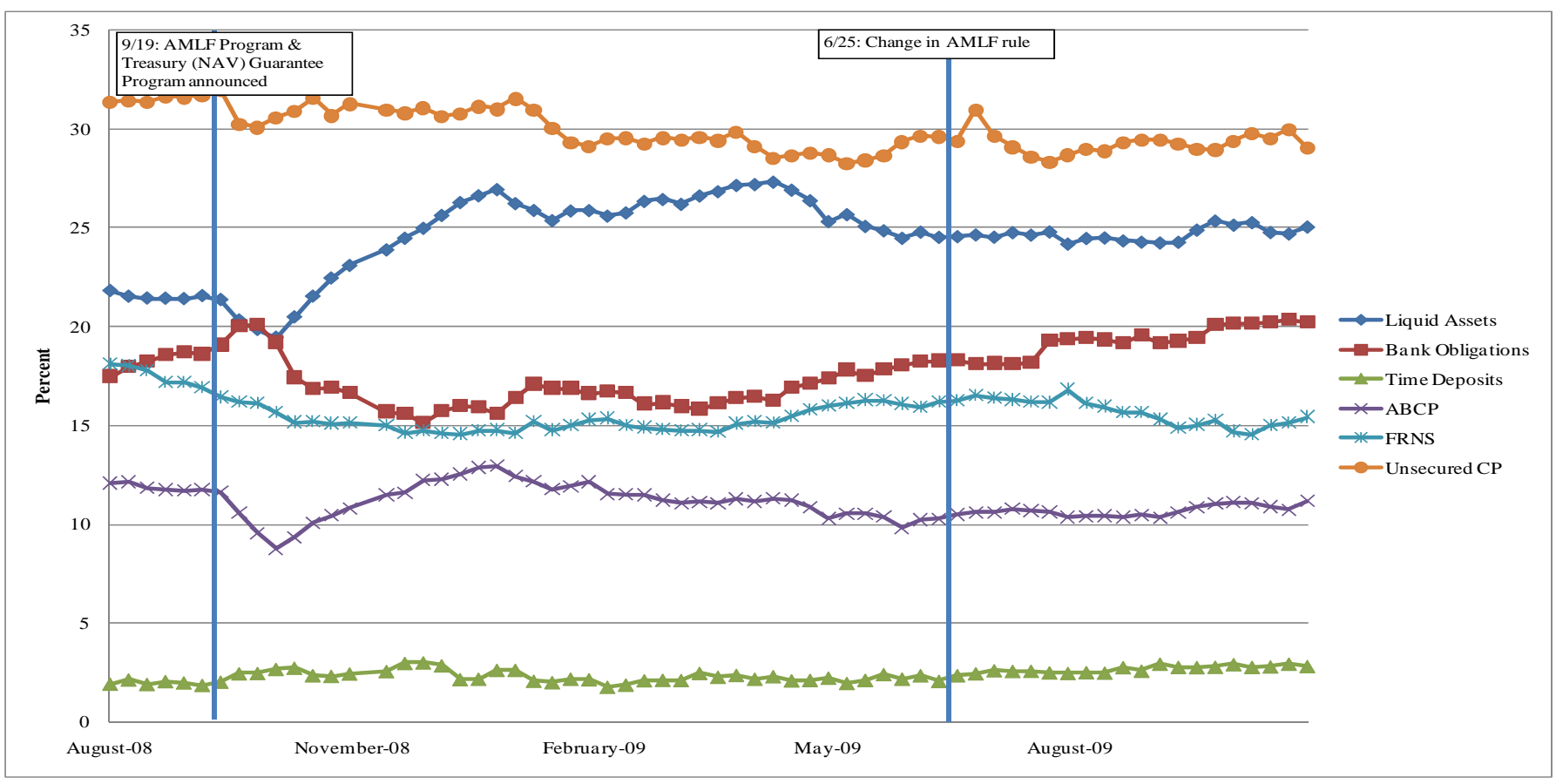

Panel B: MMMFs that participated in the AMLF

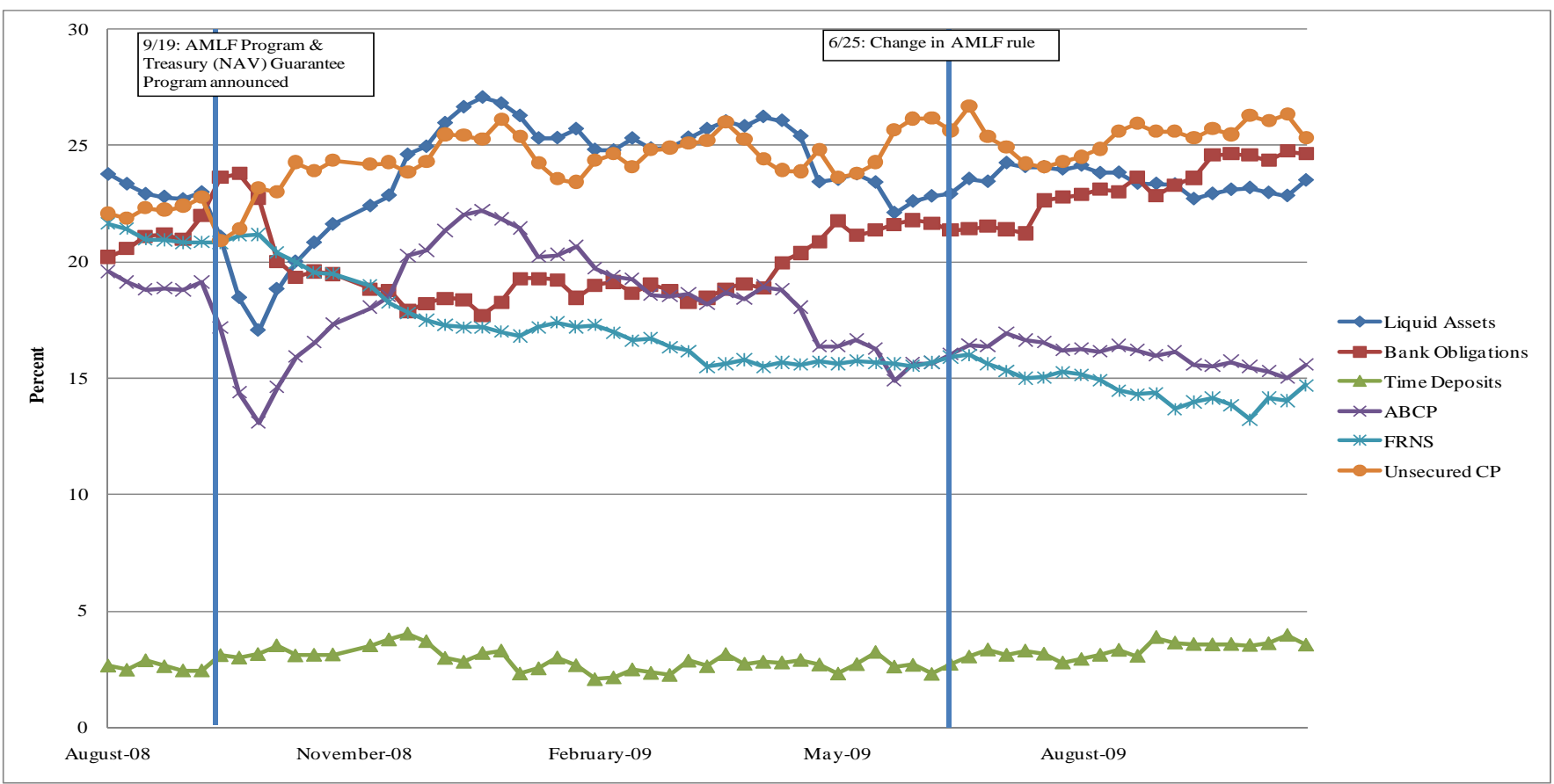

Source: iMoneyNet. 
Table 1: Concentration of asset-backed commercial paper (ABCP) programs in the ABCP Money Market Mutual Fund Liquidity Facility (AMLF)

\begin{tabular}{cccc}
\hline $\begin{array}{c}\text { Percentile of Loans } \\
(\$)\end{array}$ & Number of Sponsors & Number of Issuers & $\begin{array}{c}\text { Par Value of Loans } \\
\text { (\$ millions) }\end{array}$ \\
\hline 0.50 & 5 & 15 & 109,052 \\
0.60 & 8 & 20 & 130,862 \\
0.70 & 11 & 28 & 152,672 \\
0.80 & 16 & 38 & 174,482 \\
0.90 & 24 & 51 & 196,293 \\
1.00 & 47 & 90 & 218,103 \\
\hline
\end{tabular}

Notes: This table is based on the full sample of AMLF loans.

Source: AMLF and DTCC data.

Table 2: Prime money market mutual fund characteristics, September 9, 2008

\begin{tabular}{lcccc}
\hline & \multicolumn{2}{c}{ All Prime Funds } & \multicolumn{2}{c}{ AMLF Participant } \\
& mean & sd & mean & sd \\
\hline Assets (daily millions \$) & 8,653 & 17,253 & 12,550 & 18,482 \\
Weighted Average Maturity (daily) & 43.51 & 11.83 & 45.38 & 9.78 \\
Fraction Maturing in 7 Days & 0.271 & 0.166 & 0.246 & 0.123 \\
Fraction of ABCP & 0.115 & 0.142 & 0.177 & 0.141 \\
Fraction of US Treasury & 0.005 & 0.028 & 0.002 & 0.007 \\
Fraction of Other US Assets & 0.097 & 0.17 & 0.050 & 0.090 \\
Fraction of Repos & 0.110 & 0.139 & 0.097 & 0.088 \\
Assets (log \$) & 7.602 & 1.946 & 8.472 & 1.645 \\
Change in Daily Assets (fraction of assets) & 0.002 & 0.021 & 0.004 & 0.018 \\
Fraction of Liquid Assets & 0.212 & 0.225 & 0.149 & 0.138 \\
Institutional (first) Indicator & 0.572 & 0.496 & 0.638 & 0.483 \\
Retail (first or second) Indicator & 0.428 & 0.496 & 0.362 & 0.483 \\
Observations & 250 & 250 & 105 & 105 \\
Funds (count) & 250 & 250 & 114 & 41 \\
Fund Complex(count) & 114 & & 105
\end{tabular}

Notes: This table reports money market fund characteristics as of September 9, 2008, revealing a snapshot of the industry before the collapse of Lehman Bankruptcy on September 15, 2008. AMLF Participant denotes participation in the AMLF program at any date when the facility operated. Funds are defined at the Master Class portfolio level.

Source: AMLF and iMoney data. 
Table 3: Use of the Asset-Backed Commercial Paper Money Market Mutual Fund Liquidity Facility (AMLF): Concentration among money market mutual funds

\begin{tabular}{cccc}
\hline $\begin{array}{c}\text { Percentile of Loans } \\
(\$)\end{array}$ & $\begin{array}{c}\text { Fund Complex } \\
\text { (count) }\end{array}$ & $\begin{array}{c}\text { Fund } \\
\text { (count) }\end{array}$ & $\begin{array}{c}\text { Par Value of Loans } \\
\text { (\$ millions) }\end{array}$ \\
\hline 0.25 & 3 & 6 & 43,916 \\
0.50 & 6 & 17 & 79,922 \\
0.75 & 11 & 38 & 117,352 \\
0.85 & 14 & 53 & 133,430 \\
0.90 & 16 & 61 & 140,615 \\
0.95 & 20 & 75 & 148,735 \\
1.00 & 41 & 105 & 156,169 \\
\hline
\end{tabular}

Notes: This table reports the cumulative distribution of loans by fund complex and individual funds for the AMLF loans that are matched to individual funds in iMoneyNet. We matched about $\$ 156$ billion in loans, and we were not able to match $\$ 62$ billion in loans. Funds and fund complexes are ordered by total borrowings from the AMLF. For example, the 3 fund complexes that borrowed the most are reported in column (2).

Source: AMLF and iMoney data.

Table 4: Use of the Asset-Backed Commercial Paper Money Market Mutual Fund Liquidity Facility (AMLF): Loan characteristics

\begin{tabular}{lcc}
\hline & \multicolumn{2}{c}{ Loan characteristics } \\
& Mean & Stand. Dev. \\
\hline Days Until Maturity & 47.11 & 34.82 \\
Amortized Cost (millions \$) & 68.14 & 78.08 \\
Par Value (millions \$) & 68.39 & 78.45 \\
Loans (count) & 2,292 & 2,292 \\
Funds (count) & 105 & 105 \\
Fund Complex (count) & 41 & 41 \\
\hline
\end{tabular}

Notes: As in Table 3, this table reports loan characteristics for AMLF loans that are matched to individual funds in iMoneyNet, which comprise our main sample throughout the paper.

Source: AMLF, iMoneyNet, and DTCC data. 
Table 5: Probit regressions on funds' decision to whether or not use the Asset-Backed Commercial Paper Money Market Mutual Fund Liquidity Facility (AMLF), pooled regressions

Dependent variable - Indicator for use of AMLF

\begin{tabular}{lcccc}
\hline & $(1)$ & $(2)$ & $(3)$ & $(4)$ \\
\hline & & & & \\
Assets (daily millions log \$) & $0.002^{* * *}$ & 0.001 & $-0.403^{* * *}$ & $0.001^{* * *}$ \\
& {$[0.002]$} & {$[0.002]$} & {$[0.105]$} & {$[0.000]$} \\
Change in Daily Assets (fraction of assets) & $-0.032^{* * *}$ & $-0.038^{* * *}$ & $0.153^{*}$ & -0.002 \\
& {$[0.005]$} & {$[0.011]$} & {$[0.085]$} & {$[0.003]$} \\
Fraction of ABCP & $0.010^{* * *}$ & $-0.047^{* * *}$ & -0.291 & $0.009^{* * *}$ \\
& {$[0.001]$} & {$[0.009]$} & {$[0.195]$} & {$[0.001]$} \\
Fraction of Liquid Assets & $-0.009^{* * *}$ & $-0.099^{* * *}$ & $-0.304^{*}$ & $-0.002^{*}$ \\
& {$[0.002]$} & {$[0.010]$} & {$[0.164]$} & {$[0.001]$} \\
Fraction Maturing in 7 Days & $0.003^{*}$ & $0.022^{* * *}$ & $0.221^{* *}$ & 0.002 \\
& {$[0.002]$} & {$[0.007]$} & {$[0.089]$} & {$[0.001]$} \\
Fund Fixed Effects & No & Yes & Yes & No \\
Month Fixed Effects & No & No & Yes & Yes \\
& & & & 30460 \\
Observations & 45282 & 19461 & 2720 & 0.148 \\
Pseudo R-squared & 0.0606 & 0.0948 & & 0.266 \\
\hline
\end{tabular}

Notes: The dependent variable is an indicator variable that equals 1 if a money fund used the AMLF on a given day. The sample is a panel of daily observations for all AMLF-eligible prime MMMFs and the complete AMLF data from September 22, 2008 through May 8, 2009. All regressions include a constant term, which is not reported. The table reports marginal effects of a probit model. Standard errors are reported in brackets.

* significant at $10 \%$; ** significant at $5 \%$; *** significant at $1 \%$.

Source: Based on authors’ calculations using AMLF and iMoneyNet data. 
Table 6: Probit regressions on funds' decision to whether or not use the Asset-Backed Commercial Paper Money Market Mutual Fund Liquidity Facility (AMLF), by sub-period

Dependent variable - Indicator for use of AMLF

\begin{tabular}{|c|c|c|c|c|c|c|}
\hline SAMPLE & $\begin{array}{c}(1) \\
\text { Sep/Oct } \\
\end{array}$ & $\begin{array}{c}(2) \\
\text { Sep/Oct } \\
\end{array}$ & $\begin{array}{c}(3) \\
\text { Nov } \\
\end{array}$ & $\begin{array}{l}(4) \\
\text { Nov } \\
\end{array}$ & $\begin{array}{c}(5) \\
\text { May09 }\end{array}$ & $\begin{array}{c}\text { (6) } \\
\text { May09 }\end{array}$ \\
\hline Assets (daily millions log \$) & $\begin{array}{c}0.009 * * * \\
{[0.001]}\end{array}$ & $\begin{array}{c}0.115^{* * *} \\
{[0.038]}\end{array}$ & $\begin{array}{c}0.000 \\
{[0.000]}\end{array}$ & $\begin{array}{c}0.001 \\
{[0.011]}\end{array}$ & $\begin{array}{c}0.001 * \\
{[0.001]}\end{array}$ & $\begin{array}{c}0.372 \\
{[0.261]}\end{array}$ \\
\hline Change in Daily Assets (fraction of assets) & $\begin{array}{c}-0.093 * * * \\
{[0.028]}\end{array}$ & $\begin{array}{l}-0.103 \\
{[0.071]}\end{array}$ & $\begin{array}{c}0.000 \\
{[0.000]}\end{array}$ & $\begin{array}{l}-0.003 \\
{[0.028]}\end{array}$ & $\begin{array}{c}0.028 \\
{[0.038]}\end{array}$ & $\begin{array}{l}-0.023 \\
{[0.305]}\end{array}$ \\
\hline Fraction of $\mathrm{ABCP}$ & $\begin{array}{c}0.068^{* * *} \\
{[0.011]}\end{array}$ & $\begin{array}{c}-0.026 \\
{[0.090]}\end{array}$ & $\begin{array}{c}0.002 \\
{[0.002]}\end{array}$ & $\begin{array}{c}-0.001 \\
{[0.007]}\end{array}$ & $\begin{array}{c}0.023^{* * *} \\
{[0.008]}\end{array}$ & $\begin{array}{c}0.245 \\
{[0.338]}\end{array}$ \\
\hline Fraction of Liquid Assets & $\begin{array}{c}-0.019 * * \\
{[0.010]}\end{array}$ & $\begin{array}{c}-0.513 * * * \\
{[0.092]}\end{array}$ & $\begin{array}{l}-0.001 \\
{[0.001]}\end{array}$ & $\begin{array}{c}0.001 \\
{[0.009]}\end{array}$ & $\begin{array}{l}-0.010 \\
{[0.007]}\end{array}$ & $\begin{array}{l}-0.471^{*} \\
{[0.258]}\end{array}$ \\
\hline Fraction Maturing in 7 Days & $\begin{array}{c}-0.021^{* *} \\
{[0.010]}\end{array}$ & $\begin{array}{c}-0.083 \\
{[0.053]}\end{array}$ & $\begin{array}{c}0.001 \\
{[0.001]}\end{array}$ & $\begin{array}{c}0.002 \\
{[0.019]}\end{array}$ & $\begin{array}{c}0.009 \\
{[0.008]}\end{array}$ & $\begin{array}{c}0.978^{* * *} \\
{[0.189]}\end{array}$ \\
\hline Fund Fixed Effects & No & Yes & No & Yes & No & Yes \\
\hline $\begin{array}{l}\text { Observations } \\
\text { Pseudo R-squared }\end{array}$ & $\begin{array}{c}7620 \\
0.0890\end{array}$ & $\begin{array}{l}2955 \\
0.117\end{array}$ & $\begin{array}{c}4234 \\
0.0870\end{array}$ & $\begin{array}{c}72 \\
0.266\end{array}$ & $\begin{array}{c}4505 \\
0.0313\end{array}$ & $\begin{array}{c}840 \\
0.0914\end{array}$ \\
\hline
\end{tabular}

Notes: The dependent variable is an indicator variable that equals 1 if a fund came to the AMLF on a given day. The sample is a panel of daily observations for all AMLF-eligible prime MMMFs. All regressions include a constant term, which is not reported. The regressions are run separately for the 3 months in which AMLF activity was significant; we drop the other months as there are too few "successes"-loans originated under the facility. The table reports marginal effects of the probit model. Standard errors are reported in brackets.

* significant at $10 \%$; ** significant at $5 \%$; *** significant at $1 \%$.

Source: Based on authors' calculations using AMLF and iMoneyNet data. 
Table 7: Funds decision to how much to pledge under the Asset-Backed Commercial Paper Money Market Mutual Fund Liquidity Facility (AMLF), pooled sample

Dependent variable - Amortized cost of pledge divided by total portfolio assets

\begin{tabular}{|c|c|c|c|c|c|}
\hline & (1) & (2) & (3) & (4) & (5) \\
\hline SAMPLE & Full & Full & Sep/Oct & Nov & May09 \\
\hline \multirow[t]{2}{*}{ Assets (daily millions log \$) } & $0.100 * * *$ & $0.105^{* * *}$ & $0.112^{* * *}$ & 0.108 & 0.042 \\
\hline & [0.015] & {$[0.015]$} & [0.019] & [0.122] & [0.052] \\
\hline \multirow[t]{2}{*}{ Change In Daily Assets (fraction of assets) } & $-2.093 * * *$ & -0.001 & $-0.950 * *$ & -0.097 & 1.336 \\
\hline & {$[0.427]$} & {$[0.014]$} & {$[0.460]$} & [2.963] & [2.181] \\
\hline \multirow[t]{2}{*}{ Fraction of ABCP } & -0.009 & $0.273 *$ & 0.239 & 0.404 & 0.117 \\
\hline & {$[0.151]$} & {$[0.151]$} & {$[0.184]$} & [1.050] & [0.631] \\
\hline \multirow[t]{2}{*}{ Fraction of Liquid Assets } & $-0.733 * * *$ & -0.239 & $-0.479 * *$ & -0.662 & -0.328 \\
\hline & {$[0.151]$} & {$[0.147]$} & {$[0.187]$} & [1.063] & [0.534] \\
\hline \multirow[t]{2}{*}{ Fraction Maturing in 7 Days } & $0.369 * * *$ & $0.381^{* * *}$ & -0.183 & 0.678 & $0.935^{*}$ \\
\hline & {$[0.134]$} & {$[0.135]$} & [0.165] & {$[0.851]$} & [0.552] \\
\hline Month Fixed Effects & No & Yes & No & No & No \\
\hline Observations & 25222 & 25222 & 4077 & 2274 & 2567 \\
\hline Pseudo R-squared & 0.036 & 0.318 & 0.044 & 0.041 & 0.010 \\
\hline
\end{tabular}

Notes: The dependent variable is the total loan amount (the amortized cost of the ABCP pledged as collateral) by a fund divided by fund total assets on a given day. The sample is a panel of daily observations for all AMLF-eligible prime MMMFs and the complete AMLF data from September 22, 2008 through May 8, 2009. All regressions include a constant term, which is not reported. The table reports coefficient estimates of an Tobit model. Standard errors are reported in brackets.

* significant at $10 \%$; ** significant at $5 \%$; *** significant at $1 \%$.

Source: Based on authors’ calculations using AMLF and iMoneyNet data. 
Table 8: Funds' decision to how much to borrow under the Asset-Backed Commercial Paper Money Market Mutual Fund Liquidity Facility (AMLF), Tobit results

Dependent variable - Amortized cost of pledge divided by lagged ABCP holdings

\begin{tabular}{|c|c|c|c|c|c|}
\hline SAMPLE & $\begin{array}{l}(1) \\
\text { Full } \\
\end{array}$ & $\begin{array}{c}(2) \\
\text { Full } \\
\end{array}$ & $\begin{array}{c}\text { (3) } \\
\text { Sep/Oct }\end{array}$ & $\begin{array}{c}(4) \\
\text { Nov } \\
\end{array}$ & $\begin{array}{c}(5) \\
\text { May09 } \\
\end{array}$ \\
\hline Assets (daily millions log \$) & $\begin{array}{c}0.032 * * * \\
{[0.005]}\end{array}$ & $\begin{array}{c}0.033^{* * *} \\
{[0.005]}\end{array}$ & $\begin{array}{c}0.036 * * * \\
{[0.006]}\end{array}$ & $\begin{array}{c}0.018 \\
{[0.016]}\end{array}$ & $\begin{array}{c}0.014 \\
{[0.014]}\end{array}$ \\
\hline Change In Daily Assets (fraction of assets) & $\begin{array}{c}-0.877 * * * \\
{[0.125]}\end{array}$ & $\begin{array}{l}-0.258^{*} \\
{[0.135]}\end{array}$ & $\begin{array}{c}-0.621^{* * *} \\
{[0.142]}\end{array}$ & $\begin{array}{c}0.000 \\
{[0.014]}\end{array}$ & $\begin{array}{c}0.451 \\
{[0.697]}\end{array}$ \\
\hline Fraction of $\mathrm{ABCP}$ & $\begin{array}{c}0.253^{* * *} \\
{[0.044]}\end{array}$ & $\begin{array}{c}0.374 * * * \\
{[0.048]}\end{array}$ & $\begin{array}{c}0.397 * * * \\
{[0.060]}\end{array}$ & $\begin{array}{c}0.173 \\
{[0.136]}\end{array}$ & $\begin{array}{c}0.360 * * \\
{[0.155]}\end{array}$ \\
\hline Fraction of Liquid Assets & $\begin{array}{c}-0.165^{* * *} \\
{[0.041]}\end{array}$ & $\begin{array}{c}-0.006 \\
{[0.040]}\end{array}$ & $\begin{array}{c}-0.011 \\
{[0.049]}\end{array}$ & $\begin{array}{c}-0.076 \\
{[0.136]}\end{array}$ & $\begin{array}{c}-0.187 \\
{[0.131]}\end{array}$ \\
\hline Fraction Maturing in 7 Days & $\begin{array}{c}0.023 \\
{[0.042]}\end{array}$ & $\begin{array}{c}0.000 \\
{[0.044]}\end{array}$ & $\begin{array}{c}-0.176^{* * *} \\
{[0.055]}\end{array}$ & $\begin{array}{c}0.086 \\
{[0.106]}\end{array}$ & $\begin{array}{c}0.132 \\
{[0.139]}\end{array}$ \\
\hline Month Fixed Effects & No & Yes & No & No & No \\
\hline $\begin{array}{l}\text { Observations } \\
\text { Pseudo R-squared }\end{array}$ & $\begin{array}{l}45282 \\
0.0632\end{array}$ & $\begin{array}{l}45282 \\
0.3751\end{array}$ & $\begin{array}{c}7620 \\
0.3050\end{array}$ & $\begin{array}{c}4234 \\
0.1290\end{array}$ & $\begin{array}{c}4505 \\
0.2735\end{array}$ \\
\hline
\end{tabular}

Notes: The dependent variable is the total loan amount by a fund on a given day, scaled by the fund's ABCP holdings in the previous day. The table reports coefficient estimates of a Tobit model. Standard errors are reported in brackets. * significant at $10 \%$; ** significant at $5 \%$; *** significant at $1 \%$.

Source: Based on authors' calculations using AMLF and iMoneyNet data. 
Table 9: Analyzing the characteristics of the Asset-Backed Commercial Paper (ABCP) conduits pledged to the ABCP Money Market Mutual Fund Liquidity Facility (AMLF) as collateral

Panel A: Dependent variable - Probability that ABCP is pledged to AMLF

\begin{tabular}{|c|c|c|c|c|c|c|c|}
\hline Sample & $\begin{array}{c}\text { Sept 19-Oct 31, } \\
2008 \\
\end{array}$ & $\begin{array}{c}\text { Nov 1-30, } \\
2008 \\
\end{array}$ & $\begin{array}{c}\text { Dec 1-31, } \\
2008 \\
\end{array}$ & $\begin{array}{c}\text { Jan 1-31, } \\
2009 \\
\end{array}$ & $\begin{array}{c}\text { Feb 1-28, } \\
2009 \\
\end{array}$ & $\begin{array}{c}\text { Mar 1-31, } \\
2009 \\
\end{array}$ & $\begin{array}{c}\text { Apr 1-May 5, } \\
2009 \\
\end{array}$ \\
\hline \multirow[t]{2}{*}{ Sponsor CDS spread } & 0.000 & $0.014^{*}$ & $0.078^{*}$ & -0.008 & $0.007 *$ & $0.043^{* *}$ & $0.029 *$ \\
\hline & {$[0.001]$} & [0.007] & [0.044] & {$[0.006]$} & [0.004] & {$[0.021]$} & {$[0.017]$} \\
\hline Program Type Fixed Effects & Yes & Yes & Yes & Yes & Yes & Yes & Yes \\
\hline Time Fixed Effects & Yes & Yes & Yes & Yes & Yes & Yes & Yes \\
\hline Observations & 2251 & 342 & 85 & 658 & 340 & 76 & 42 \\
\hline Pseudo R-squared & 0.291 & 0.35 & 0.236 & 0.0834 & 0.0541 & 0.176 & 0.533 \\
\hline
\end{tabular}

Panel B: Dependent variable - Probability that ABCP is pledged to AMLF

\begin{tabular}{|c|c|c|c|c|c|c|c|}
\hline Sample & $\begin{array}{c}\text { Sept 19-Oct 31, } \\
2008\end{array}$ & $\begin{array}{c}\text { Nov 1-30, } \\
2008\end{array}$ & $\begin{array}{c}\text { Dec 1-31, } \\
2008\end{array}$ & $\begin{array}{c}\text { Jan 1-31, } \\
2009 \\
\end{array}$ & $\begin{array}{c}\text { Feb 1-28, } \\
2009\end{array}$ & $\begin{array}{c}\text { Mar 1-31, } \\
2009\end{array}$ & $\begin{array}{c}\text { Apr 1-May 5, } \\
2009\end{array}$ \\
\hline \multirow[t]{2}{*}{ Sponsor CDS spread } & 0.000 & $0.003^{* *}$ & $0.003^{*}$ & -0.003 & 0.001 & $0.003^{* *}$ & $0.001 *$ \\
\hline & {$[0.001]$} & {$[0.001]$} & {$[0.002]$} & [0.003] & {$[0.001]$} & {$[0.002]$} & [0.001] \\
\hline Program Type Fixed Effects & Yes & Yes & Yes & Yes & Yes & Yes & Yes \\
\hline Time Fixed Effects & No & No & No & No & No & No & No \\
\hline Observations & 3056 & 1515 & 1849 & 1914 & 1634 & 864 & 888 \\
\hline Pseudo R-squared & 0.0342 & 0.293 & 0.0936 & 0.0217 & 0.024 & 0.102 & 0.161 \\
\hline
\end{tabular}

Notes: The dependent variable is the probability that asset-backed commercial paper (ABCP) issued by a given conduit is pledged to the AMLF on a given day. The sample is a panel of daily observations for all conduits that issue AMLF-eligible paper in the U.S. market (non-extendible issues rated at least A-1/P-1). All regressions include dummies for ABCP program type (multi-seller, single-seller, securities arbitrage, and structured investment vehicle). Sponsor CDS Spread is the premium on the 5-year credit default swap of the program sponsor (measured in percent) as reported by Moody's and is taken from Markit. The table reports marginal effects of a probit model. Robust standard errors clustered by sponsor are reported in brackets.

* significant at $10 \%$; ** significant at $5 \%$; *** significant at $1 \%$.

Source: Based on authors’ calculations using AMLF, DTCC, and Markit data. 
Table 10: Impact of the Asset-Backed Commercial Paper Money Market Mutual Fund Liquidity Facility (AMLF) on money market mutual fund asset flows

Dependent variable - Percentage change in assets under management

\begin{tabular}{|c|c|c|c|c|c|c|c|c|}
\hline & $(1)$ & $(2)$ & $(3)$ & $(4)$ & $(5)$ & $(6)$ & $(7)$ & $(8)$ \\
\hline AMLF Program Indicator & $\begin{array}{c}-0.002 \\
{[0.005]}\end{array}$ & $\begin{array}{c}-0.010^{* *} \\
{[0.005]}\end{array}$ & $\begin{array}{c}-0.002 \\
{[0.005]}\end{array}$ & $\begin{array}{c}-0.002 \\
{[0.005]}\end{array}$ & $\begin{array}{c}-0.002 \\
{[0.005]}\end{array}$ & $\begin{array}{c}-0.010^{* *} \\
{[0.005]}\end{array}$ & $\begin{array}{c}-0.002 \\
{[0.005]}\end{array}$ & $\begin{array}{c}-0.011^{* *} \\
{[0.004]}\end{array}$ \\
\hline AMLF Program Indicator X Fraction of ABCP (on 16 September 2008) & $\begin{array}{c}0.083 * * * \\
{[0.030]}\end{array}$ & $\begin{array}{c}0.083 * * * \\
{[0.030]}\end{array}$ & $\begin{array}{c}0.081^{* * *} \\
{[0.029]}\end{array}$ & $\begin{array}{c}0.081^{* * *} \\
{[0.029]}\end{array}$ & $\begin{array}{c}0.083 * * * \\
{[0.030]}\end{array}$ & $\begin{array}{c}0.083 * * * \\
{[0.030]}\end{array}$ & $\begin{array}{c}0.081 * * * \\
{[0.029]}\end{array}$ & $\begin{array}{c}0.081^{* * * *} \\
{[0.029]}\end{array}$ \\
\hline Fraction of ABCP (on 16 September 2008) & $\begin{array}{c}-0.087 * * * \\
{[0.025]}\end{array}$ & $\begin{array}{c}-0.087 * * * \\
{[0.025]}\end{array}$ & & & $\begin{array}{c}-0.074 * * * \\
{[0.022]}\end{array}$ & $\begin{array}{c}-0.074 * * * \\
{[0.022]}\end{array}$ & & \\
\hline Fraction Maturing in 7 Days (on 16 September 2008) & & & & & $\begin{array}{c}-0.003 \\
{[0.025]}\end{array}$ & $\begin{array}{c}-0.003 \\
{[0.025]}\end{array}$ & & \\
\hline Fraction of Liquid Assets (on 16 September 2008) & & & & & $\begin{array}{c}0.023 \\
{[0.029]}\end{array}$ & $\begin{array}{c}0.023 \\
{[0.029]}\end{array}$ & & \\
\hline Institutional Fund Indicator & & & & & $\begin{array}{c}-0.014 * * * \\
{[0.003]}\end{array}$ & $\begin{array}{c}-0.014 * * * \\
{[0.003]}\end{array}$ & & \\
\hline Day Fixed Effects & No & Yes & No & Yes & No & Yes & No & Yes \\
\hline Fund Fixed Effects & No & No & Yes & Yes & No & No & Yes & Yes \\
\hline Observations & 2644 & 2644 & 2644 & 2644 & 2644 & 2644 & 2644 & 2644 \\
\hline R-squared & 0.015 & 0.025 & 0.009 & 0.020 & 0.027 & 0.036 & 0.009 & 0.020 \\
\hline
\end{tabular}

Notes: The dependent variable is the percentage change in assets under management for a given fund. The sample is a panel of daily observations for all prime funds in the United States. AMLF Program Indicator is a dummy variable that equals 1 after September 19, 2008, when the AMLF was implemented. Robust standard errors clustered by sponsor are reported in brackets. * significant at $10 \%$; ** significant at $5 \%$; *** significant at $1 \%$.

Source: Based on authors' calculations using AMLF and iMoneyNet data. 
Table 11: Impact of the Asset-Backed Commercial Paper Money Market Mutual Fund

\section{Liquidity Facility (AMLF) on asset-backed commercial paper (ABCP) yields}

Dependent variable - Yield on ABCP minus yield on commercial paper issued by the sponsor

\begin{tabular}{|c|c|c|c|c|c|c|}
\hline & $(1)$ & $(2)$ & (3) & (4) & (5) & (6) \\
\hline \multirow[t]{2}{*}{ Post-AMLF Indicator } & $-0.787 * * *$ & $0.777^{* *}$ & $-0.987 * * *$ & $-0.881^{* * *}$ & -0.336 & \\
\hline & [0.218] & {$[0.278]$} & {$[0.275]$} & {$[0.271]$} & [0.273] & \\
\hline \multirow[t]{2}{*}{ Sponsor CDS Spread } & & 0.122 & $-0.259 * *$ & 0.059 & 0.025 & -0.269 \\
\hline & & {$[0.072]$} & {$[0.098]$} & [0.128] & [0.106] & [0.462] \\
\hline \multirow[t]{2}{*}{ AMLF Participant Indicator } & & & & & -0.842 & -0.899 \\
\hline & & & & & {$[0.676]$} & {$[0.603]$} \\
\hline \multirow[t]{2}{*}{ Post-AMLF Indicator X AMLF Participant Indicator } & & & & & $-0.685^{* *}$ & $-0.873 * *$ \\
\hline & & & & & {$[0.265]$} & {$[0.271]$} \\
\hline \multirow[t]{2}{*}{ Constant } & $2.752 * * *$ & $2.437 * * *$ & $1.522 * * *$ & $1.462 * * *$ & $2.293 * * *$ & $2.390 * * *$ \\
\hline & {$[0.151]$} & {$[0.091]$} & [0.277] & {$[0.231]$} & {$[0.585]$} & {$[0.677]$} \\
\hline Conduit Fixed Effects & No & Yes & No & No & No & No \\
\hline ABCP Program Type Fixed Effects & No & No & Yes & Yes & Yes & Yes \\
\hline Sponsor Fixed Effects & No & No & No & Yes & Yes & Yes \\
\hline Time Fixed Effects & No & No & No & No & No & Yes \\
\hline Observations & 201 & 185 & 185 & 185 & 185 & 185 \\
\hline R-squared & 0.135 & 0.723 & 0.304 & 0.458 & 0.548 & 0.642 \\
\hline
\end{tabular}

Notes: The dependent variable is the overnight yield on asset-backed commercial paper (ABCP) issued by a conduit minus the overnight yield on unsecured commercial paper issued by the financial institution sponsoring the ABCP conduit. The sample is a panel of daily observations for conduits that issue AMLF-eligible paper in the U.S. market (non-extendible issues rated at least A-1/P-1) from September 16 to September 24, 2008. We match conduits with sponsors using reports by Moody's Investors Service. Data on yields are from DTCC. Post-AMLF Indicator is an indicator variable that equals 1 after September 19, 2008, when the AMLF was implemented. Sponsor CDS Spread is the premium on the 5-year credit default swap of the ABCP program sponsor measured in percent and is from Markit. AMLF User is a dummy variable that equals 1 for ABCP programs pledged to the AMLF over its first month of operation. ABCP program types are multi-seller, single-seller, securities arbitrage, structured investment vehicle, and other. Robust standard errors clustered by sponsor are reported in brackets.

* significant at $10 \%$; ** significant at $5 \%$; *** significant at $1 \%$.

Source: Based on authors’ calculations using data from AMLF, DTCC, and Markit data. 
Table 12: Stock returns of money fund managers around the launch of the Asset-Backed Commercial Paper Money Market Mutual Fund Liquidity Facility (AMLF)

Dependent Variable: Stock return between September 18 and September 22, 2008

\begin{tabular}{|c|c|c|c|c|c|}
\hline & $(1)$ & $(2)$ & $(3)$ & $(4)$ & $(5)$ \\
\hline Money fund exposure? $(\mathrm{Yes}=1, \mathrm{No}=0)$ & $\begin{array}{c}0.0455^{*} \\
{[0.0259]}\end{array}$ & & & & \\
\hline Money fund assets managed / Market capitalization & & $\begin{array}{c}0.0024 * * * \\
{[0.0004]}\end{array}$ & $\begin{array}{c}0.0018^{* * *} \\
{[0.0005]}\end{array}$ & $\begin{array}{c}0.0024 * * * \\
{[0.0004]}\end{array}$ & $\begin{array}{c}0.0018^{* * *} \\
{[0.0006]}\end{array}$ \\
\hline Prime money fund assets managed / Money fund assets managed & & & $\begin{array}{c}0.1099 * * \\
{[0.0478]}\end{array}$ & & $\begin{array}{c}0.1104^{* *} \\
{[0.0481]}\end{array}$ \\
\hline ABCP assets managed / Prime money fund assets managed & & & & $\begin{array}{c}0.0012 * * * \\
{[0.0004]}\end{array}$ & $\begin{array}{c}0.0014^{* * *} \\
{[0.0004]}\end{array}$ \\
\hline $\log$ ( Market capitalization ) & $\begin{array}{c}0.0190 * \\
{[0.0113]}\end{array}$ & $\begin{array}{c}0.0282 * * * \\
{[0.0102]}\end{array}$ & $\begin{array}{c}0.0220^{* *} \\
{[0.0104]}\end{array}$ & $\begin{array}{c}0.0283^{* * *} \\
{[0.0103]}\end{array}$ & $\begin{array}{c}0.0221 * * \\
{[0.0105]}\end{array}$ \\
\hline Constant & $\begin{array}{c}-0.3069 * \\
{[0.1802]}\end{array}$ & $\begin{array}{c}-0.4495 * * * \\
{[0.1662]}\end{array}$ & $\begin{array}{c}-0.3591 * * \\
{[0.1682]}\end{array}$ & $\begin{array}{c}-0.4523^{* * *} \\
{[0.1674]}\end{array}$ & $\begin{array}{c}-0.3618^{* *} \\
{[0.1695]}\end{array}$ \\
\hline Observations & 94 & 94 & 94 & 94 & 94 \\
\hline R-squared & 0.068 & 0.067 & 0.107 & 0.068 & 0.108 \\
\hline
\end{tabular}

Notes: The dependent variable is the price return of holding the stock of a company from September 18 to September 22, 2008, obtained from CRSP and DataStream. The sample is the union of the set of financial companies in the S\&P500 index as of September 19, 2008 and the set of publicly traded companies reported by iMoneyNet as managers of money market mutual funds (MMMFs). Money fund exposure is a dummy variable that equals 1 for MMMF managers reported by iMoneyNet as of September 19, 2008. Money fund assets is the sum of assets at all MMMFs managed by a company as of September 19, 2008. Prime money fund assets represents the sum of assets at all prime MMMFs managed by a company as of September 19. Finally, ABCP assets is the sum of asset-backed commercial paper (ABCP) holdings at all MMMFs managed by a company as of September 15, 2008. Robust standard errors are reported in brackets. * significant at $10 \%$; ** significant at $5 \%$; *** significant at $1 \%$.

Source: Based on authors' calculations using data from iMoneyNet, CRSP, and DataStream. 